\title{
Change Detection and Trend Analysis of Future Temperature and Rainfall over West Africa
}

\author{
Oluwaseun W. Ilori ${ }^{1}$ (D) Vincent O. Ajayi ${ }^{1}$
}

Received: 1 May 2020 / Accepted: 14 August 2020 / Published online: 30 August 2020

(c) The Author(s) 2020

\begin{abstract}
This paper examined future trends with change detection in temperature and rainfall over three agro-climatic zones of West Africa. Historical (1961-2000) and projection (2020-2099) data of ensemble-mean of six RCMs that dynamically downscaled five GCMs that participated in CMIP5 obtained from Co-Ordinated Regional Climate Downscaling Experiment (CORDEX) were used. Standard normal homogeneity, Buishand's, Pettitt's, and Mann-Kendall test were used for change point detection and trend analysis at 5\% significant level. Inter-annual anomaly and projected change in the seasonal cycle relative to historical mean were investigated. The ensemble-mean evaluation performed for the historical period (1961-2000) using CRU dataset revealed that the change point occurred in rainfall and temperature series in the 1970s and 1980s, while a significant increasing trend is observed in temperature in all climatic zones. Change-point detection test projects rainfall series to be homogeneous as significant change point is expected to occur in temperature for all zones under RCP4.5 and RCP8.5 for near (2020-2059) and far-future (2060-2099). For the near-future, an increase in the mean temperature between $0.5-1.30{ }^{\circ} \mathrm{C}$ and $0.19-1.67{ }^{\circ} \mathrm{C}$ is projected to occur under RCP4.5 and RCP8.5 respectively. Projected relative change in seasonal cycle shows that winter months may witness increase in rainfall amounts under RCP4.5 but significantly dry under RCP8.5 in near and far-future as temperature is expected to become warmer in all months. Rainfall anomaly projects the Sahel to have a reduced amount of rainfall compared to other zones as temperature anomaly reveals a continuous increase in all the zones under the two RCPs. The results of this study show that climate change will intensify in West Africa in the future.
\end{abstract}

Keywords West africa $\cdot$ CORDEX $\cdot$ Climatic zones $\cdot$ Change detection $\cdot$ Mann-kendall trend analysis $\cdot$ Regional climate models

\section{Introduction}

Intergovernmental Panel on Climate Change (IPCC) Fifth Assessment Report (AR5) projected a continuous increase in global temperature (IPCC 2007a) as a result of: increasing fossil fuel combustion and greenhouse gases (GHG) emission, significant changes in land-use/land-cover due to industrialization and urbanization and natural processes like earthquake (IPCC 2007b). These natural processes and human-induced (anthropogenic) forces have contributed significantly to the modification of climate pattern (IPCC 2007a) over the world, leading to intensification

Oluwaseun W. Ilori

hilorywilson@gmail.com

1 Department of Meteorology and Climate Science, Federal University of Technology, Akure, PMB 704, Akure, Ondo State, Nigeria of El Nino events, increase in the occurrence of extreme weather events (Akinsanola and Zhou 2018; Gbode et al. 2019), increase in the ocean and land surface temperature (IPCC 2014), changes in spatio-temporal pattern of rainfall and temperature (Sylla et al. 2016) and sea level rise (IPCC 2014). These continuous changes in climate and weather pattern requires continuous investigation and analysis of trends with change point detection in climatic variables in all the regions of the world (Vincent et al. 2015; Savitskaya 2010). Food and Agriculture Organization (FAO 2001) reported and confirmed that in Africa and West Asia, crop yield that depends on atmospheric temperature variation reduced by $15-35 \%$ while reduction of about $25-35 \%$ were recorded in the Middle East because of the rise in mean temperature from 2 to $4{ }^{\circ} \mathrm{C}$. In addition to variation in temperature and rainfall, Ravindran et al. (2000) and Sivakumar et al. (2012) further listed windspeed, evapotranspiration solar radiation and relative humidity among many other climatic variables 
that affect agriculture sector, water supply and hydroelectric power sector.

At the global and regional scales, the climate has changed significantly. In the United State, the United States Climate Change Science Program (CCSP 2008) reported that there have been increased in the intensity and frequency of heavy precipitation in North America. Vincent et al. (2015) reported a decreasing trend in the percentage of cold nights and increase in the percentage of warm nights over the South America region. Over Asia, it was also reported by Savitskaya (2010) that the entire region has become warmer in winter while there was also a high variability in precipitation patterns for the last five decades. From the analysis of daily mean temperature in Japan using linear regression, Gaussian binomial low-pass filter, non-linear, and non-parametric trend test, Schaefer and Domroes (2009) noticed an increasing annual temperature trend from $0.35{ }^{\circ} \mathrm{C}$ to $2.93{ }^{\circ} \mathrm{C}$ from the year 1901-2000 (100 years). Global mean temperature increment of about $0.7^{\circ} \mathrm{C}$ since the last century has been reported by (IPCC 2007b). In Africa, the temperature has been increasing at about $0.15^{\circ} \mathrm{C} /$ decade (Collins 2011). It is important to point out that the extent of change in temperature, rainfall, and all other climatic variables are not spatially and temporally uniform across the world (IPCC 2014; Yue and Hashino 2003). This regional variation is as a result of the differences in surface albedo, types of land surfaces, evapotranspiration and GHG emission rate among many other factors affecting the climate in many forms (Meissner et al. 2003; Synder et al. 2004).

Bhavnani et al. (2008), Badou et al. (2017) and Hounkpè et al. (2016) pointed out that starting from the decade of 1970s, sub-Saharan Africa region has been experiencing increasing natural disasters with a noticeable severe flood and drought of 2010 and 2012 respectively in central and western Africa that affected more than 1.5 millions of people and death of 340. In west Africa, due to their high dependence on rainfall for daily socio-economic activities and inadequate coping capacities, extreme weather events have high negative impacts on the socio-economic activities of the people of West Africa (Ahmed et al. 2009). Furthermore, in West Africa, it is expected that there will be an increase in the occurrence of weather and climate extreme events (IPCC 2007) as a result of uncertainties in the pattern of climate variables. Recently, Ajayi and Ilori (2020) revealed in their analysis of projected drought events using one regional climate model that a distinct dry period is expected from the 2060s till the end of the century in West Africa while the first half of the twenty-first century will be a humid period. Over West Africa, Sylla et al. (2016) reported a significant increase in air temperature indicating projected and continuous warming up to $6.5{ }^{\circ} \mathrm{C}$ with -30 to $30 \%$ uncertainty range in precipitation. In a similar work Adefisan (2018) examined impact of climate change on temperature and rainfall distributuion over West Africa to project increase in rainfall and temperature under three scenarios A2, A1B and B1 of the IPCC. Ayansina and Ogunbo (2009) reported that ongoing climate change has led to increased rainfall in the region. Over the mono river watershed in Togo and Benin, Emmanuel et al. (2019) projected an increasing trend in rainfall and temperature between 2018-2050 under RCP4.5 and RCP8.5 whereas, rainfall will be highly characterized by inter-annual variabilities due to change in the mean of temperature. On record, West Africa has witnessed noticeable and immense variability in rainfall such as the 1970s and 1980s droughts to recent frequent flooding (Nicholson 2013). Lin et al. (2014), Ibrahim et al. (2014) and Sanogo et al. (2015) revealed that the Sahel has recovered from the drought of 1970s and 1980s and human-induced aerosol precursor emission with increasing GHG in the atmosphere could be causes of this recovery (Biasutti 2013; Dong and Sutton 2015) while natural variability might not be left out (Mohino et al. 2011).

The 5th assessment report of the IPCC (IPCC 2013) projected that global surface temperature increment relative to a pre-industrial age (1850-1900) may exceed $1.5^{\circ} \mathrm{C}$ by the end of the twenty-first century and could be higher or lower at different regions. Therefore, assessing this climate projection under different RCPs to know the nature and magnitude of the change over West Africa will help the policymakers in choosing the rightful and relevant action to mitigate against the impeding socio-economic impacts of projected extreme climate events in West Africa. However, earlier similar limited studies that examined trends and change point detection in climate variables (Akinsanola and Ogunjobi 2015; Oguntunde et al. 2011; Fasona et al. 2011; Ati et al. 2002) focused on a single country in West Africa using historical in-situ observation dataset while Emmauel et al. (2019) that make use of single RCM under RCP4.5 and RCP8.5 did not extend their work beyond 2050 over Mono watershed in West Africa. Hence, this present study aimed at using ensemble mean of six Regional Climate model (RCMs) that participates in the Co-Ordinated Regional Climate Downscaling Experiment (CORDEX; Giorgi et al. 2009) to assess trends and change point detection in rainfall and temperature over West Africa from 2020 to 2099. The ensemble mean of multiple RCMs and host of individual RCMs have been shown to replicate the pattern of West Africa climate and features like West African Monsoon very well though with varying degree of skills (Lambert and Boer 2001; Kim et al. 2014; Akinsanola et al. 2015; Ajayi and Ilori 2020). Most of these models, however, are good enough for use in this study.

In testing for change point detection and trend analysis, the non-parametric and parametric statistical approach can be used to know if a given set of data has a trend or follows a distribution at a fixed significance level. The change detection test is important in reducing uncertainty 
in climate information given to policymakers and other end-users (Jaiswal and Lohani 2015; Vezzoli et al. 2012). Non-parametric test such as Pettit's test (Mauget 2003; Yu et al. 2006), Standard Normal Homogeneity (GonzalezRouco et al. 2001; Stepanek et al. 2009) test, Buishand's range test (Buishand 1982; Jaiswal and Lohani 2015) and Mann-Kendall trend test (MK; Kendall 1975; Wang et al. 2005; Karmeshu 2012) used in this study have the capability to identify an abrupt change and gradual trend superimposed on a climate variables. These tests have been widely used to detect change point and examined the trend in series of hydro-climatic variables like temperature, rainfall, wind speed, humidity and sunshine hour (Salarijazi et al. 2012; Sivakumar et al. 2012; Jaiswal and Lohani 2015; Emmanuel et al. 2019; Ajayi and Ilori 2020). The Pettit's test, SNHT, Buishand's range test, and MK trend test were used and performed over the three homogeneous agro-climatic zones of West Africa.

\section{Data and Methodology}

\subsection{Study Area}

Figure 1 shows the study area of West Africa. West Africa consist of sixteen countries with a total landmass area of about $6,140,000 \mathrm{~km}^{2}$ and an estimated population above 381 million people (WPP 2019). West Africa is located between latitude $0^{\circ}$ and $20^{\circ} \mathrm{N}$, longitude $20^{\circ}$ and $20^{\circ} \mathrm{E}$, bounded in the southern part by the Atlantic Ocean which plays an important role in the monsoon of West Africa and the far north by Algeria and Libya. Using ecosystem, climate, and weather pattern and land-use/land-cover similarity Omotosho and Abiodun 2007, Abiodun et al. 2013, divided west

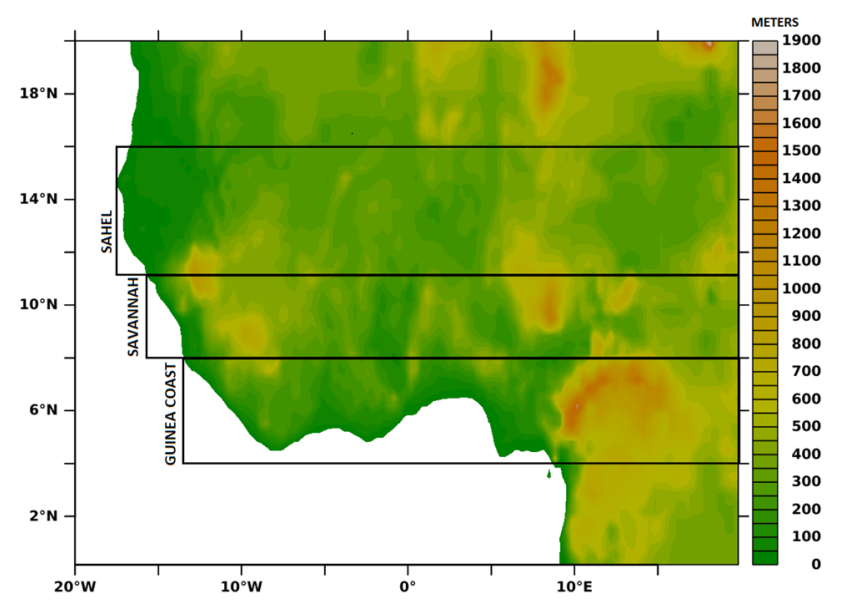

Fig. 1 Map of West Africa showing the three climatic zones and elevation at $100 \mathrm{~m}$ interval ( adopted from Omotosho and Abiodun 2007)
Africa into three zones namely; Guinea coast, Savannah and Sahel with the latitudinal belt of $4^{\circ}-8^{\circ} \mathrm{N}, 8^{\circ}-11^{\circ} \mathrm{N}$, and $11^{\circ}-16^{\circ} \mathrm{N}$ respectively. West African rainfall patterns follow the seasonal movement of the Inter-Tropical Discontinuity (ITD) zone that reached its northernmost position of $21^{\circ}-22^{\circ} \mathrm{N}$ in August (Nicholson 2013) and the northward movement of the southwesterly monsoon flow, the northern migration of ITD leads to a bimodal pattern of rainfall within the Guinea coast and little dry season (LDS) in August. The other two zones (Savannah and Sahel) have an unimodal rainfall pattern with a peak in August. From the Sahel far north to the Guinea coast near the Atlantic Ocean, annual rainfall ranges from $400 \mathrm{~mm}$ in the Sahel to over $2000 \mathrm{~mm}$ in the Guinea coat (Oguntunde et al. 2011; Akinsanola et al. 2015). Observed zonal variation in the amount of rainfall in West Africa is due to the abrupt latitudinal migration of highest precipitation from the Guinea coast to the Sahel in June (Sultan and Janicot 2003; Le Barbe et al. 2002), this was referred to as the 'monsoon jump' by Lebel (2003) and Hagos and Cook (2007). Complex topography like Cameroon highlands that bound West Africa in the east, Fouta Djallon, and Jos Plateau in Nigeria greatly influence the West African climate.

\subsection{Data}

Ensemble mean of six RCMs driven by five different Coupled Modelling Intercomparison Project (CMIP5) GCMs participating in the CORDEX (Nikulin et al. 2018) is used in this study. The findings from the performance evaluation of CORDEX RCMs datasets in simulating temperature and rainfall over West Africa using either the ensemble mean of different RCMs or individual RCM shows that these selected RCMs (Table 1) obtained from the CORDEX archieve performed better in replicating the pattern of rainfall and temperature (Nikulin et al. 2012; Gbobaniyi et al. 2014; Akinsanola et al. 2015; Ajayi and Ilori 2020). The simulation spanned from 1950 to 2100 . These RCMs dynamically downscaled five GCM simulations at a horizontal resolution of $0.44^{\circ} \times 0.44^{\circ}$ (Dieterich et al. 2013; Panitz et al. 2014). Daily temperature and rainfall that later converted to monthly data were utilized from the dataset over the three climatic zones of West Africa. Here in this study, the performance of the ensemble mean in simulating seasonal cycle, trend and change point detection was evaluated using the gridded dataset of Climate Research Unit (CRU: Harris et al. 2014) version v4.03. Table 1 highlight all the RCMs used and their driven GCMs.

The historical part of this work covers forty years (1961-2000) and future climate projection is from 2020 to 2099. The future period is further divided into near-future (2020-2059) and far-future (2060-2099). This was done to examine the implication of exceeding a GWL of $2{ }^{\circ} \mathrm{C}$ in 
Table 1 RCM simulations and the dynamically downscaled GCMs for the ensemble mean used in the study

\begin{tabular}{lll}
\hline Institute & GCMs & Downscaling RCMs \\
\hline Max planck institute for meteorology (Germany) & MPI-M-MPI-ESM-LR & REMO \\
Consortium of european research institution and researchers & ICHEC-EC-EARTH & RACMO, CCLM \\
Commonwealth scientific and industrial research organization & CSIRO-MK3-6-0 & RCA4 \\
NOAA geophysical fluid dynamics laboratory, USA & NOAA-GFDL-GFDL-ESM2M & RCA4 \\
Canadian centre for climate modeling and analysis (Canada) & CCCma-CanESM2 & CRCM5 \\
\hline
\end{tabular}

West Africa. The analyses were performed for RCP4.5 and RCP8.5 pathways that represent mid-level emission scenarios and high-level emission scenario respectively (van Vuuren et al. 2011). Till the end of the twenty-first century, Moss et al. (2010) described how the CMIP5 GCM projection was being forced by the RCPs.

\subsection{Change-Point Detection}

To examine the period when a significant change happened in the time series of variables, a test for change point detection is an essential approach. Standard Normal Homogeneity Test, Buishand's range, and Pettitt's test that has been used widely for this purpose in climate-related fields (Gallagher et al. 2012; Jaiswal and Lohani 2015) were used in this study to examine changes and variabilities in rainfall and temperature over West Africa. These three change point tecniques are all non-parametric test that do not require any assumption about the distribution of rainfall and temperature data. They give an indication when the change in mean of temperature and rainfall occurs (Vezzoli et al. 2012). The details of the three change point tests used in this study are described below.

\subsubsection{Standard Normal Homogeneity Test (SNHT)}

Standard Normal Homogeneity (SNHT) firstly developed by Alexandersson (1986) and later reviewed and improved to examine and detect a change in a time series of rainfall data (Alexandersson and Moberg 1997). Following Stepanek et al. (2009) and Vezzoli et al. (2012), test statistic $\left(T_{k}\right)$ can be used in comparing the mean of first observations $(n)$ with the remaining mean of the observations $(n-k)$ having $n$ number of data points:

$T_{k}=k Z_{a}^{2}+(n-k) Z_{b}^{2}$

From Eq. (1) $Z_{a}$ and $Z_{b}$ can then be computed as:

$Z_{a}=k^{-1} \sum_{i=1}^{k} \frac{x_{i}-\bar{x}}{\sigma x}$

$Z_{b}=(n-k)^{-1} \sum_{i=k+1}^{k} \frac{x i-\bar{x}}{\sigma x}$,

where $\bar{x}$ is the mean and $\sigma x$ is the standard deviation of the series. Year $k$ is the change point that consists of a break when $T_{k}$ value reaches its maximum. To reject the null $\left(H_{0}\right)$ hypothesis, the critical value should be less than a test statistic that further depends on the size of the observation $(n)$ highlighted in Table 2.

\subsubsection{Buishand's Range Test}

Buishand's range test also known as Buishand's test developed by Buishand (1982), is a test that can be used on variables with any type of distribution but has been studied majorly for normal distribution. The cumulative deviation from the average for the nth number of observation for a
Table 2 Test statistics critical values used for SNHT, Buishand's and Pettitt's test change point detection (sourced from Winingaard et al. 2003)

\begin{tabular}{|c|c|c|c|c|c|c|}
\hline \multirow[t]{3}{*}{ Number of samples } & \multicolumn{6}{|c|}{ Test statistic critical level at two significant levels } \\
\hline & \multicolumn{2}{|l|}{ SNHT } & \multicolumn{2}{|c|}{ Buishand's test } & \multicolumn{2}{|c|}{ Pettitt's test } \\
\hline & $1 \%$ & $5 \%$ & $1 \%$ & $5 \%$ & $1 \%$ & $5 \%$ \\
\hline 20 & 9.56 & 6.95 & 1.6 & 1.43 & 71 & 57 \\
\hline 30 & 10.45 & 7.65 & 1.7 & 1.5 & 133 & 107 \\
\hline 40 & 11.01 & 8.1 & 1.74 & 1.53 & 208 & 167 \\
\hline 50 & 11.38 & 8.45 & 1.78 & 1.55 & 293 & 235 \\
\hline 70 & 11.89 & 8.8 & 1.81 & 1.59 & 488 & 393 \\
\hline 100 & 12.32 & 9.15 & 1.86 & 1.62 & 841 & 677 \\
\hline
\end{tabular}


series $x_{1}, x_{2}, x_{3}, \ldots x_{k}$ having mean $(\bar{x})$ is the partial adjusted $\operatorname{sum}\left(S_{n}\right)$ and can be computed as:

$S_{n}=\sum_{i=1}^{n}(x-\bar{x})$.

In a random series, a series may be homogeneous without change point if $S_{n} \cong 0$ so that the deviation from the mean will be distributed on the negative and positive side of the mean. By rescaling the adjusted range $(R)$, the significance of change (shift) can be determined with the equation below:

$$
R=\frac{\operatorname{Maximum}\left(S_{n}\right)-\operatorname{Minimum}\left(S_{n}\right)}{\bar{x}} .
$$

The critical values highlighted by Buishand (1982) together with Winingaard et al. (2003) in Table 2 are then compared with the calculated value of $R / \sqrt{ } n$.

\subsubsection{Pettitt's Test}

Pettitt's test is a non-parametric test that can be performed without any distribution assumption about the data, it was developed by Pettitt (1979) and became very useful in assessing the presence of abrupt changes in climatic data (Mu et al. 2007; Gao et al. 2011). Because of its sensitivity to break in any time series, Pettitt's test has been widely used for change point detection (Winingaard et al. 2003). The test statistics used in Pettitt's have been explained by Dhorde and Zarenistanak (2013) and Kang and Yusof (2012). From the Pettitt's test, $x_{1}, x_{2}, x_{3}, \ldots x_{n}$ represent observed series of data with a change point at time $t$ such that $x_{1}, x_{2}, x_{3}, \ldots x_{t}$ having $G_{1}(x)$ as the distribution function of the first part of the series that different from the second distribution function $G_{2}(x)$ of the series $x_{t+1}, x_{t+2}, x_{t+3}, \ldots x_{t+n} . U_{t}$ which is the non-parametric test statistics is defined as follows:

$U_{t}=\sum_{i=1}^{t} \sum_{j=t+1}^{n} \operatorname{sign}\left(x_{t}-x_{j}\right)$,

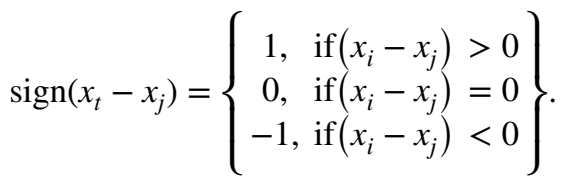

For $n$ length of the sample, the confidence level $(\rho)$ and test statistics $K$ can be explained as:

$$
\begin{aligned}
& K=\operatorname{Max}\left|U_{t}\right|, \\
& \rho=\exp \left(\frac{-K}{n^{2}-n^{3}}\right) .
\end{aligned}
$$

The null $\left(H_{0}\right)$ hypothesis is rejected while the alternate $\left(H_{a}\right)$ is accepted when the specified confidence level is greater than $\rho$. At any change point, the approximate significant probability was defined as:

$P=1-\rho$,

where a noticeable shift in the data exists (change point), the whole series of the data is divided into two sub-series at the point where the change point occurred. At 51 and $1 \%$ confidence level, Table 2 presents the critical values used for Pettit's test, Buishand's test, and SNHT performed in the analysis.

\subsubsection{Trend Analysis}

Mann-Kendall test (MK; Mann 1945; Wang et al. 2005; Kendall 1975) is used to assess historical and projected trends under RCP4.5 and RCP8.5. Being a non-parametric test with low sensitivity to short break because of inhomogeneous time series (Tabari et al. 2011) and the data needed not to be normally distributed, MK statistic can be described as:

$$
K=\sum_{i=1}^{n} \sum_{j=1}^{i-1} \operatorname{sign}\left(x_{i}-x_{j}\right)
$$

where $x_{i}$ and $x_{j}$ are the values of the two sequential generic data, $n$ is the data total length while $\operatorname{sign}\left(x_{i}-x_{j}\right)$ gets the following values:

$\operatorname{sign}\left(x_{t}-x_{j}\right)=\left[\begin{array}{cc}1, & \text { if }\left(x_{i}-x_{j}\right)>0 \\ 0, & \text { if }\left(x_{i}-x_{j}\right)=0 \\ -1, & \text { if }\left(x_{i}-x_{j}\right)<0\end{array}\right]$.

The variance $\operatorname{Var}(S)$ can be calculated as follows when $S$ statistic is approximately distributed with the $E(S)$ mean:

$E(S)=0$,

$\operatorname{Var}(S)=n^{-1}\left\{n(n-1)(2 n+5)-\sum_{t} t(t-1)(2 t+5)\right\}$,

where $t$ is any given tie extent, $\sum t$ represents the addition of all values of the tie number and $n$ denotes length of the series. The $Z$ standardized statistics for the test can then be evaluated using the equation below:

$Z=\left\{\begin{array}{cc}-1, & \text { if } K<0 \\ 0, & \text { if } K=0 \\ \frac{S+1}{\sqrt{\operatorname{Var}(S)}} & \text { if } K>0\end{array}\right\}$ 
Positive (negative) value of the $Z$ test statistic represents an increasing (decreasing) trend in the series. From the test, the null $\left(H_{0}\right)$ hypothesis is accepted when the dataset of $n$ with variables randomly distributed independently without trend with ordering equally likely. To determine the significance of the trend, the absolute value of $Z$ (test statistic) is then compared with the values of $Z\left(1-\frac{p}{2}\right)$ at $p$ percentage level of significance gotten from table to reject or accept the $H_{0}$.

\subsection{Seasonal Cycle and Inter-Annual Variability}

Projected percentage change in the seasonal cycle of temperature and rainfall relative to baseline mean (1961-2000) under RCP4.5 and RCP8.5 was computed with the Eq. (14).

$P_{n}=\left(\frac{R_{n}-B_{n}}{B_{n}}\right) \times 100$

where $P_{n}$ is the projected percentage change relative to historical long-term mean for an nth month, $R_{n}$ is the mean projected temperature or rainfall for month $n$ (long-term monthly mean) and $B_{n}$ is the mean obtained from the baseline years (long-term mean) of the ensemble mean. This follows the method of Emmanuel et al. (2019)

Also, rainfall and temperature anomaly index were used to examine the impacts of climate variability and change on West Africa climate in the near and far future under the two RCPs considered in this study. Following Alexander et al. (2006), in computing the anomaly, historical long-term mean from the ensemble mean is used to determine how the future climate will deviate from the period of 1961-2000.

\section{Results and Discussion}

\subsection{Ensemble Evaluation Using Seasonal Cycle, Change Detection Test and Trend Analysis}

The seasonal cycle and pattern of the monthly mean of rainfall and temperature over the three climatic zones are presented in Fig. 2 for the historical period of 1961-2000 for both CRU observation and ensemble-mean dataset. This helps to understand the capability of the ensemble mean in replicating seasonal distribution of temperature and rainfall and also how it captured temperature and rainfall amplitudes and phases over the three climatic zones compared to CRU observation. There are two peaks of rainfall over the Guinea Coast (Fig. 2) with a primary peak in June and a secondary peak in September as also observed with the CRU. In August, there is relatively noticeable minimum rainfall (midsummer low) because of the north and south movements of the monsoon rain band (Cook 1999; Paeth et al. 2011;
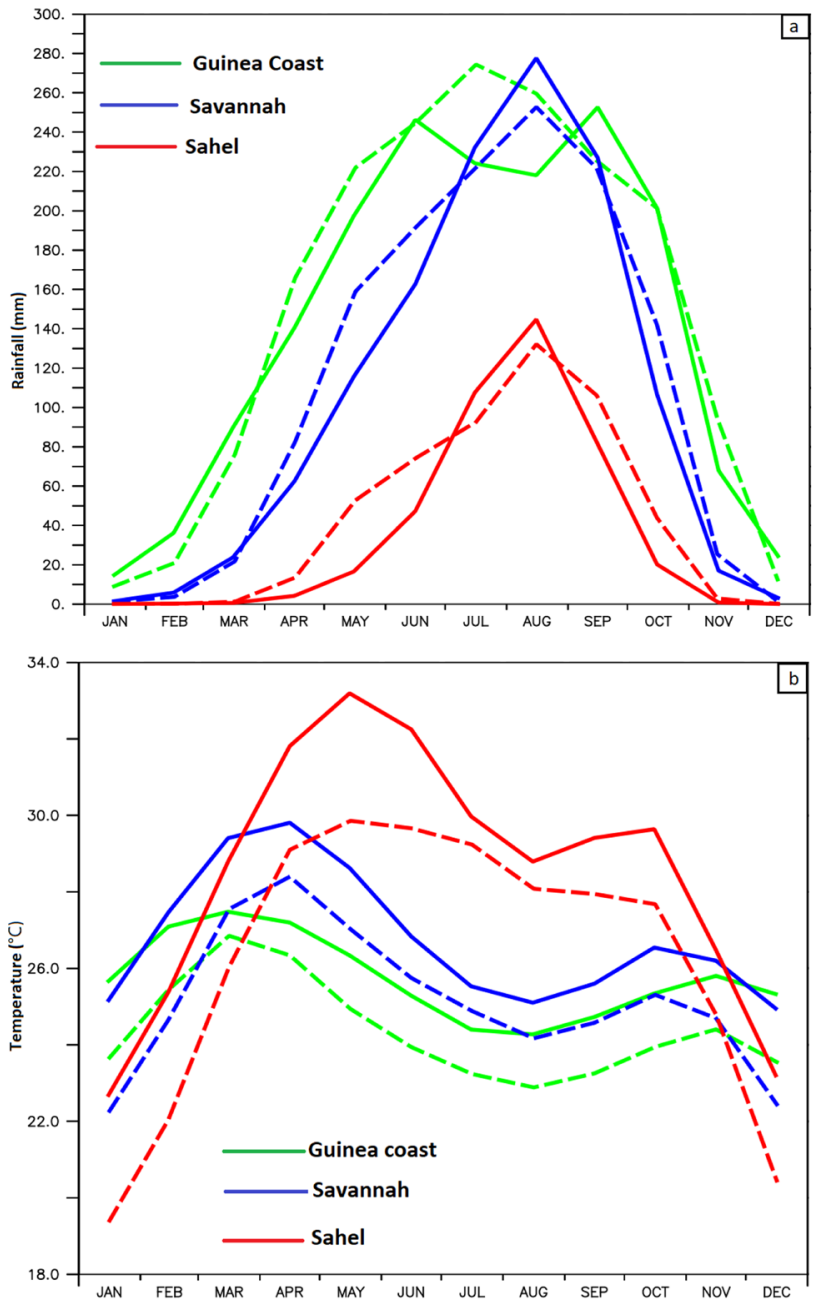

Fig. 2 Seasonal cycle of rainfall (a) and temperature (b) over the three climatic zone, bold and broken lines represent CRU and ensemble mean, respectively

Sylla et al. 2013). However, over the Guinea Coast, ensemble mean shows a little difference noticeable in its number of peaks and rainfall intensities. Both CRU and ensemble mean to agree to a maximum reduction in temperature at the peak of the monsoon months (August). Over the Savannah and Sahel, observed is a single peak of rainfall in August (unimodal rainfall pattern) while the temperature in the Savannah is warmer than the Guinea Coast and warmest in the Sahel. In the Savannah, period of rainy season observed to be from May-September while it is within four months (June-September) in the Sahel. Notice over the Savannah and Sahel as it is also observed over the Guinea Coast is the bias in the monthly values of rainfall and temperature between CRU and ensemble mean. The mid-summer low rainfall observed over the Guinea Coast has been reported by Gbobaniyi et al. (2014), Diallo et al. (2013), and Sultan and Janicot (2003). This occurs between June and July resulting 
from the northward migration of monsoon precipitation as far as $10^{\circ} \mathrm{N}$ that produce more than $90 \%$ of rainfall in the Sahel (Fink 2003; Omotosho and Abiodun 2007) that further leads to a higher amount of rainfall within the Sahel in August. It can be seen that ensemble mean reproduce rainfall and temperature pattern over the three climatic zones but with overestimation and underestimation in some months. This can be associated to different parameterization schemes used in the various RCMs that made up the ensemble mean (Afiesimama et al. 2006; Diallo et al. 2012) as this was recently observed by Ajayi and Ilori (2020).

In performing change detection analysis, annual mean temperature and rainfall average over the Guinea Coast, Savannah, and the Sahel was analyzed using Buishand's test, SNHT, and Pettitt's test for the historical period (1961-2000) at a significant level of 5\%. Test statistics of the three tests together with the null $\left(H_{0}\right)$ hypothesis rejection and acceptance are presented in Tables 3 and 4 for rainfall and temperature respectively. Figures 3, 4, and 5 are the graphical representation of ensemble-mean temperature series with a change point over the three climatic zones of West Africa. In identifying change point in rainfall and temperature the following method was adopted and have been used by Winingaard et al. (2003) and Jaiswal et al. (2015)

1. Change-point did not occur or homogeneous (HGN): series of rainfall or temperature may be regarded as homogeneous when one or non of the test rejected the null $\left(H_{0}\right)$ hypothesis at a significant level of $5 \%$.

2. Change-point occurs or heterogeneous (CPT): rainfall and temperature series may have shift (change point) or heterogeneous when two or the three tests reject the null $\left(H_{0}\right)$ at a significant level of $5 \%$.

3. Doubtful (DBF) series: at a significant level of 5\%, a series of rainfall or temperature is regarded as doubtful and evaluated further when the three tests failed to agree on when the change point occurred.

From Table 3, as observed from CRU observation homogeneity state, the rainfall series of Guinea Coast and Savannah show a significant change point as both the SNHT and Buishand's agree that rainfall series over these two climatic zones are inhomogeneous. Over the Guinea Coast, the change point occurred in 1979 while it is in 1983 for the Savannah. Generally, the rainfall series from the Sahel is homogeneous. Likewise, it is observed from the ensemble mean that in 1984, a significant change point occurred in the rainfall series of Guinea Coast while the Sahel rainfall series is also homogeneous. Over the Savanna, the nature of the rainfall series is doubtful as the three tests could not agree on the change point. This could be because Buishand's and Pettitt's test are very sensitive to identify changes at the

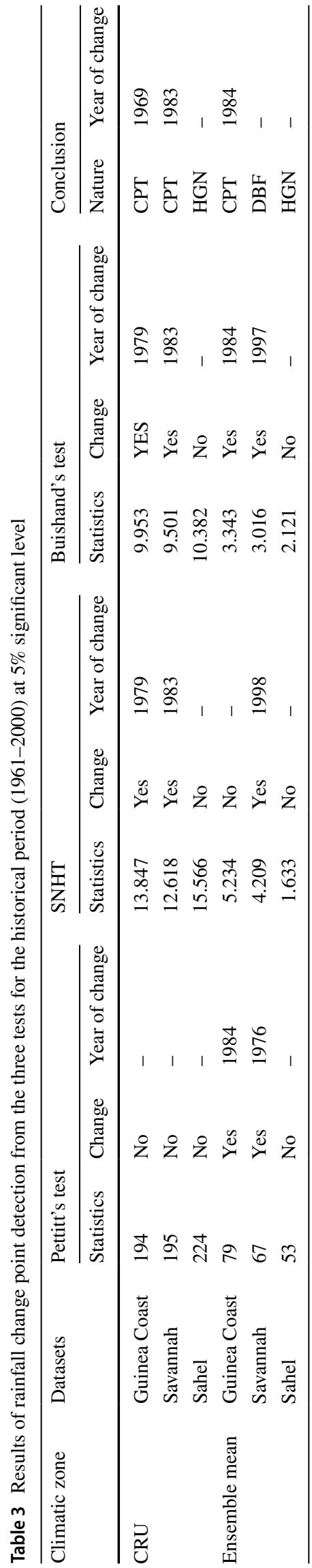




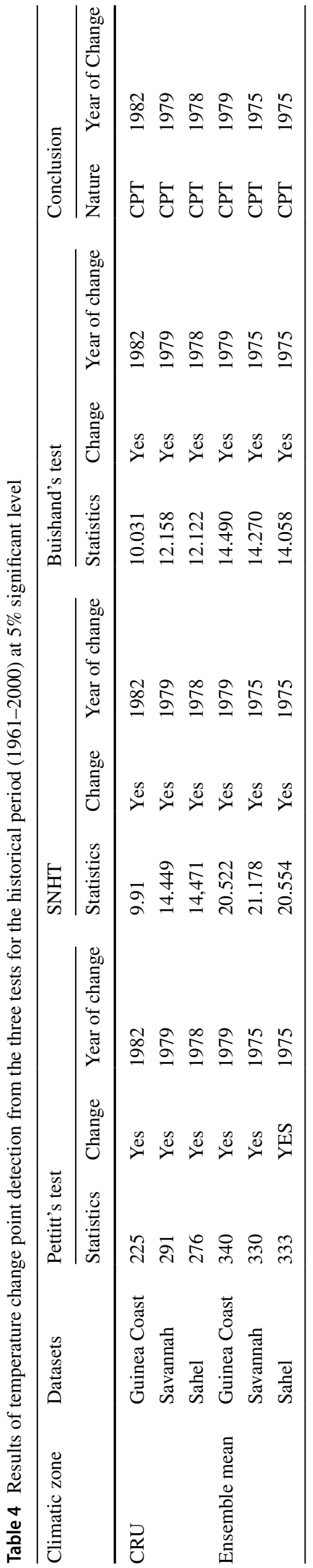

middle of a series, whereas SNHT is well known to locate change point at the beginning and end of a series of data (Winingaard et al. 2003; Jaiswal and Lohani 2015). The change point noticed from the CRU and ensemble mean agreed to have occurred in the 1970s and 1980s, these two decades are decades of well know drought in west Africa (Le Barbé et al. 2002; Lebel and Ali 2009; Nicholson 2013) that resulted in significant low rainfall amount. Likewise, frequent sand storm and buildup of atmospheric dust (Ekpoh and Nsa 2011) have been suspected to contribute to variability in rainfall in these decades, global and regional pattern of sea surface temperature (Adeniyi and Oladiran 2000) and weakened circulation of global monsoon (Pant 2003) also contributed to change point observed in rainfall over the three zones. Between 1960-2000, the result (Table 4) of change point detection in temperature over the Guinea Coast, Savannah and Sahel zones of west Africa show a significant shift in mean (change point) that occurred between 1975 and 1982 within the same decades of the 1970s and 1980s of well-known droughts of west Africa. Human activities that lead to increasing greenhouse gases emission (Charney et al. 1977; Sylla et al. 2016) and global climate shift identified by Baines (2006) could be the contributing factors that cause change point in temperature.

Table 5 depicts the results of the Mann-Kendall trend test at 5\% significant level performed over the three climatic zones for temperature and rainfall. From the ensemble mean and CRU temperature series, temperature showed a significant increasing trend at a significant level of 5\% with magnitude (Sen's slope) that ranges between 0.0078 lowest in the Guinea Coast and 0.0253 highest in the Sahel. CRU rainfall trend analysis over Guinea Coast and the Sahel indicated a significant decrease in total annual rainfall at a 5\% significant level and a non-significant decreasing trend over the Savannah. A non-significant decreasing trend in the ensemble-mean rainfall was observed over the three climatic zones of West Africa as it has been already reported by Akinsanola and Ogunjobi (2014), Nicholson 2013 and Emmanuel et al. (2019). Climate change as a result of global warming due to numerous human activities has been identified as a major cause of the decreasing and increasing trend of rainfall over West Africa (IPCC 2013; Sylla et al. 2016).

\subsection{Near-Future Rainfall and Temperature Pattern}

\subsubsection{Change Detection and Trend Analysis}

The results of change-point detection performed using SNHT, Pettitt's, and Buishand's test for the ensemble mean of temperature and rainfall are presented in Table 6 while Table 7 shows the result of Mann-Kendall test under RCP4.5 and RCP8.5 for the near-future (2020-2059). The results of change-point detection (homogeneity) show that under RCP4.5, change 
Fig. 3 Change point in the temperature time-series average over Guinea Coast as depicted by Pettitt's test (a), SNHT (b), and Buishand's test (c). Where $\mu 1$ and $\mu 2$ are the mean temperature before and after change point has occurred respectively (a)
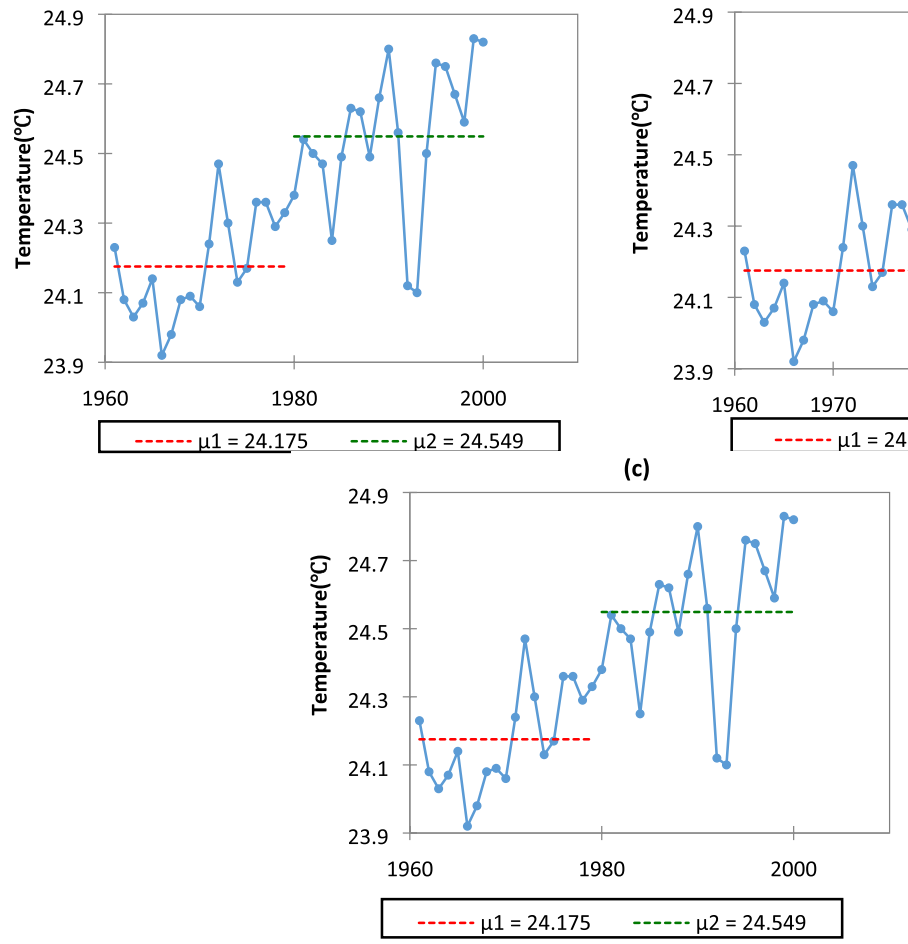

(a)

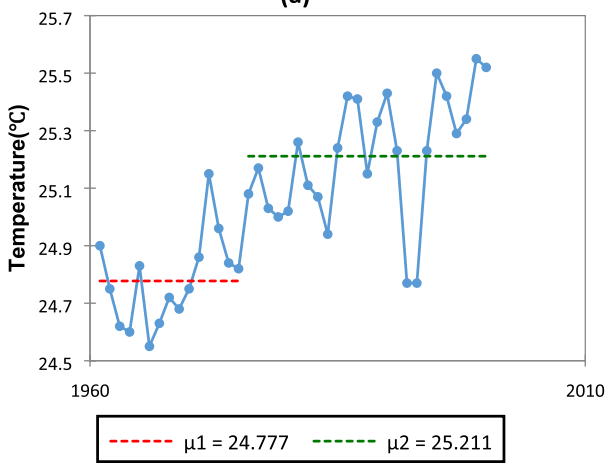

$\mu 2=24.549$ (b)

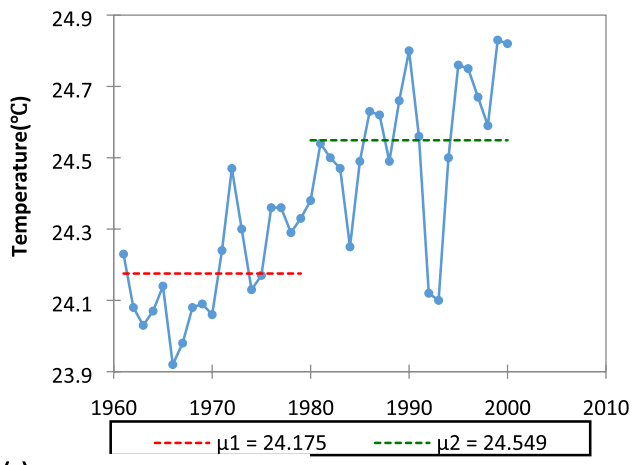

Fig. 4 Change point in the temperature time-series average over the Savannah as depicted by Pettitt's test (a), SNHT (b), and Buishand's test (c). Where $\mu 1$ and $\mu 2$ are the mean temperature before and after change point has occurred respectively

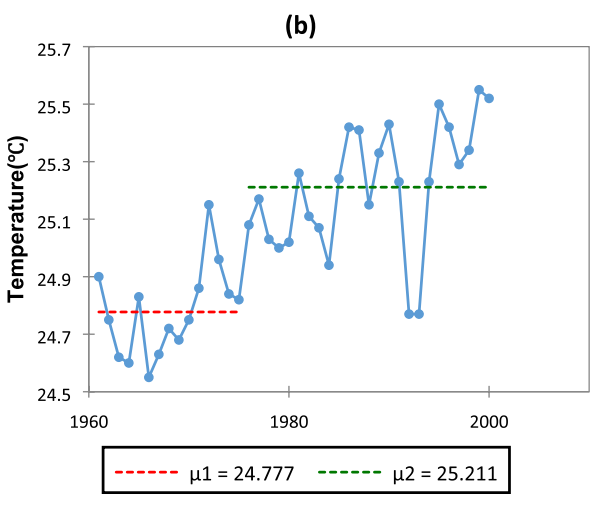

(c)

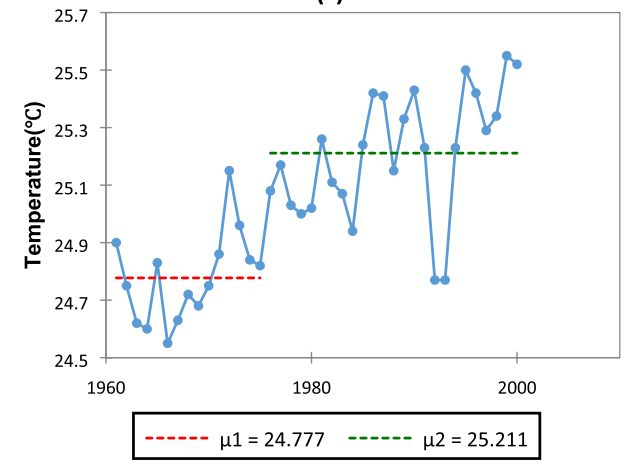


Fig. 5 Change point in the temperature time-series average over the Sahel as depicted by Pettitt's test (a), SNHT (b), and Buishand's test (c). Where $\mu 1$ and $\mu 2$ are the mean temperature before and after change point has occurred respectively (a)

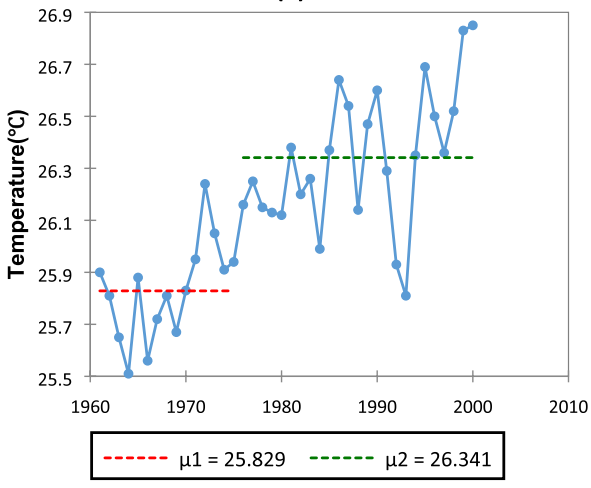

(b)

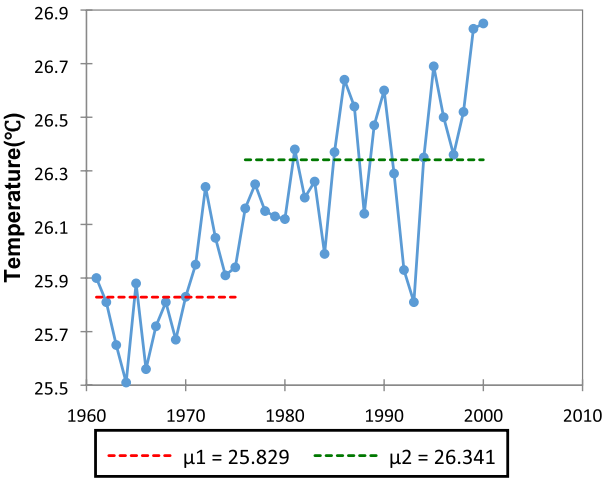

(c)

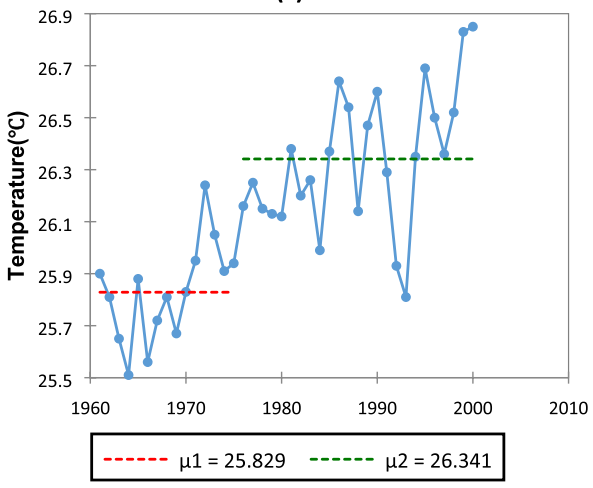

Table 5 Mann-Kendall trend test of rainfall and temperature at a $5 \%$ significance level over the three climatic zones of West Africa at 5\% significant level for the historical period (1961-2000)

\begin{tabular}{|c|c|c|c|c|c|c|}
\hline \multirow[t]{2}{*}{ Scenario } & \multirow[t]{2}{*}{ Climatic zone } & \multicolumn{3}{|l|}{ Rainfall } & \multicolumn{2}{|c|}{ Temperature } \\
\hline & & $P$ value & & Sen's slope & $P$ value & Sen's slope \\
\hline \multirow[t]{3}{*}{ CRU } & Guinea Coast & 0.0403 & -3.306 & & 0.0168 & 0.0078 \\
\hline & Savannah & 0.1959 & -2.195 & & 0.0007 & 0.0133 \\
\hline & Sahel & 0.0180 & -3.387 & & 0.0001 & 0.0200 \\
\hline \multirow[t]{3}{*}{ Ensemble mean } & Guinea Coast & 0.5758 & -0.394 & & 0.0001 & 0.0230 \\
\hline & Savannah & 0.9907 & 0.101 & & 0.0065 & 0.0215 \\
\hline & Sahel & 0.8704 & -0.094 & & 0.0001 & 0.0253 \\
\hline
\end{tabular}

Bold figures represent a statistically significant trend

Table 6 Conclusion from the results of change point analysis of near-future ensemble-mean rainfall and temperature over the three climatic zones under RCP4.5 and RCP8.5 at 5\% significant level

\begin{tabular}{|c|c|c|c|c|c|c|c|c|c|c|c|}
\hline \multirow[t]{2}{*}{ Scenario } & \multirow[t]{2}{*}{ Climatic zone } & \multicolumn{5}{|l|}{ Rainfall } & \multicolumn{5}{|c|}{ Temperature } \\
\hline & & $\begin{array}{l}\text { Nature of } \\
\text { the series }\end{array}$ & Year of change & $\mu 1$ & $\mu 2$ & diff & $\begin{array}{l}\text { Nature of } \\
\text { the series }\end{array}$ & Year of change & $\mu 1$ & $\mu 2$ & diff \\
\hline \multirow[t]{3}{*}{$\mathrm{RCP} 4.5$} & Guinea Coast & HGN & - & 2151.95 & - & & $\mathrm{CPT}$ & 2036 & 26.12 & 26.64 & 0.52 \\
\hline & Savannah & HGN & - & 1612.58 & - & & DBF & - & - & - & - \\
\hline & Sahel & $\mathrm{HGN}$ & - & 755.47 & - & & $\mathrm{CPT}$ & 2037 & 27.6 & 28.29 & 0.69 \\
\hline \multirow[t]{3}{*}{ RCP8.5 } & Guinea Coast & HGN & - & 1761.45 & - & & СРТ & 2040 & 27.59 & 28.76 & 1.17 \\
\hline & Savannah & $\mathrm{CPT}$ & 2044 & 1544.53 & 1649.70 & 105.18 & СРТ & 2040 & 28.39 & 29.61 & 1.22 \\
\hline & Sahel & HGN & - & 792.09 & - & & $\mathrm{CPT}$ & 2040 & 29.48 & 30.78 & 1.30 \\
\hline
\end{tabular}

$\mu 1$ and $\mu 2$ are the mean before and after the change point has occurred 
Table 7 Result of trend analysis of near-future ensemble-mean rainfall and temperature under RCP4.5 and RCP8.5 at 5\% significant level

\begin{tabular}{lllllll}
\hline Scenario & $\begin{array}{l}\text { Climatic } \\
\text { zone }\end{array}$ & \multicolumn{2}{l}{ Rainfall } & & \multicolumn{2}{l}{ Temperature } \\
\cline { 6 - 7 } RCP4.5 & Guinea & 0.7093 & -0.500 & & $\mathbf{0 . 0 0 0 9}$ & 0.025 \\
& Coast & & & & & \\
& Savannah & 0.5292 & 0.511 & & $\mathbf{0 . 0 0 0 7}$ & 0.029 \\
& Sahel & 0.6082 & 0.181 & & $\mathbf{0 . 0 0 2 8}$ & 0.033 \\
RCP8.5 & Guinea & 0.5920 & 0.986 & & $\mathbf{0 . 0 0 2 1}$ & 0.057 \\
& Coast & & & & \\
& Savannah & 0.1958 & 1.754 & $\mathbf{0 . 0 0 1 9}$ & 0.059 \\
& Sahel & 0.4773 & 0.916 & & $\mathbf{0 . 0 0 0 1}$ & 0.063 \\
\hline
\end{tabular}

Bold figures represent a statistically significant trend

point in rainfall series will not occur over the three climatic zones and this is the same under RCP8.5 over the Guinea Coast and the Sahel. A change-point is likely to occur in rainfall amount over the Savannah that could lead to an increase in the mean of total annual rainfall from 1544.53 to $1649.70 \mathrm{~mm}$ by the year 2044 under RCP8.5 (Table 6). For the temperature series under RCP4.5, a change point expected to occur over the Guinea Coast and the Sahel by the year 2036 and 2037 respectively that may be as a result of the projected increase in the annual mean of temperature within the range of 0.52-0.69 ${ }^{\circ} \mathrm{C}$ in the near future (Table 6). A positive shift in the mean of annual temperature likely to take place in all the three climatic zones by the year 2040 within the range of 1.17 and $1.30{ }^{\circ} \mathrm{C}$ in the near-future under higher emission scenario. Trend analysis of temperature (Table 7) results reveal that in the near-future temperature will be marked by a significant increase in its annual mean with magnitude (Sen's slope) of change expected to be between 0.025 and 0.033 under RCP 4.5 while it could be between 0.057 and 0.063 under RCP8.5 over the three climatic zones of West Africa. Rainfall time series present no trend and are homogeneous statistically as it is observed from Table 7. Emmanuel et al. (2019) in their change-point detection test and trend analysis reported that there is neither a linear trend nor a change point in time series of annual rainfall in Mono river watershed located between Togo and Benin republic. These results are also similar to the findings of Nelson et al. (2010), N'Tcha M'Po et al. (2017) and Lawin et al. (2018) but with a projected increase in annual mean temperature between 0.59 ${ }^{\circ} \mathrm{C}$ and $1.30{ }^{\circ} \mathrm{C}$. This further confirms that west Africa will continue to be warmer than before.

\subsubsection{Projected Relative Change in Seasonal Cycle Change and Inter-Annual Anomaly}

On a long-term seasonal scale, the expected changes in temperature and rainfall seasonal cycle under RCP4.5 and RCP8.5 relative to the historical period are shown in Fig. 6.
The relative change in monthly rainfall under RCP4.5 (Fig. 6a) projects an increase that could be up to $60 \%$ in all seasons for the Guinea Coast with the highest to be recorded in the winter season (Dec, Jan, Feb). This projected increase in seasonal rainfall is also observed in the Savannah for most of the month with the highest relative projected change of about $62 \%$ in December. However, over the Sahel, the expected relative change varies from -14\% in March to $73 \%$ in January. Under higher emission rate (Fig. 6b), the months of July, August, September, and October are projected to witness a relative increase in monthly rainfall up to $22 \%$ in all the climatic zones but there could be a general decrease in rainfall to about $57 \%$ in November, December, and February. However, the projected relative decrease/increase in monthly rainfall expected to be highest in the Sahel under RCP8.5. Moreover, the projected change in temperature seasonal cycle (Fig. $5 \mathrm{c}, \mathrm{d}$ ) relative to historical period shows a general increase that varies from 5 to $11.3 \%$ under RCP4.5 and from 11 to $24.1 \%$ under RCP8.5 over the three climatic zones. Under the two RCPs, the highest increase in temperature will take place in the winter season (December, January, February) while Guinea Coast and Savannah will be warmer than the Sahel in pre-monsoon and monsoon months.

Figure 7 represents the total annual rainfall anomaly relative to the historical long-term mean over the three climatic zones. This was done to examine the extent to which the total annual rainfall in the near-future will deviate from the longterm total annual mean of the historical period. It is observed over the Guinea Coast that all years in the near-future show a positive deviation. This means that total annual rainfall in near-future will be generally higher in comparison with the reference period. The total rainfall amount could be as high as $500 \mathrm{~mm} /$ year wetter under RCP4.5 (Fig. 7a). Most of the years before the year 2046 will be negatively deviated up to $-400 \mathrm{~mm}$ lower (Fig. 7b) by 2039 under RCP 8.5 over the same zone of Guiea Coast. The high positive deviation noticed over the Guinea Coast will be reduced in the Savannah under RCP4.5. Likewise, under RCP8.5 and over the Savannah also, most of the years are expected to be wetter as the year 2033, 2038, 2039, 2041 and 2043 will be drier years. However, Sahel under RCP4.5 and RCP8.5 will be negatively deviated (Fig. 7e, f), this shows that Sahel will witness a significant reduction in total annual rainfall in the near future even if the current GHG emission is maintained or increased. Moreover, the annual mean temperature anomaly relative to the historical mean shows a positive deviation (warmer temperature) in the near-future with temperature under RCP8.5 warmer than that of RCP4.5 in all the three homogeneous climatic zones (Fig. 8) and deviation in the Sahel greater than other two climatic zones. Continuous human activities (Farmer and Wigley 1985; Charney et al. 1977) as an important factor in bio-geophysical feedback mechanism (BFM) have been suspected together with a shift 

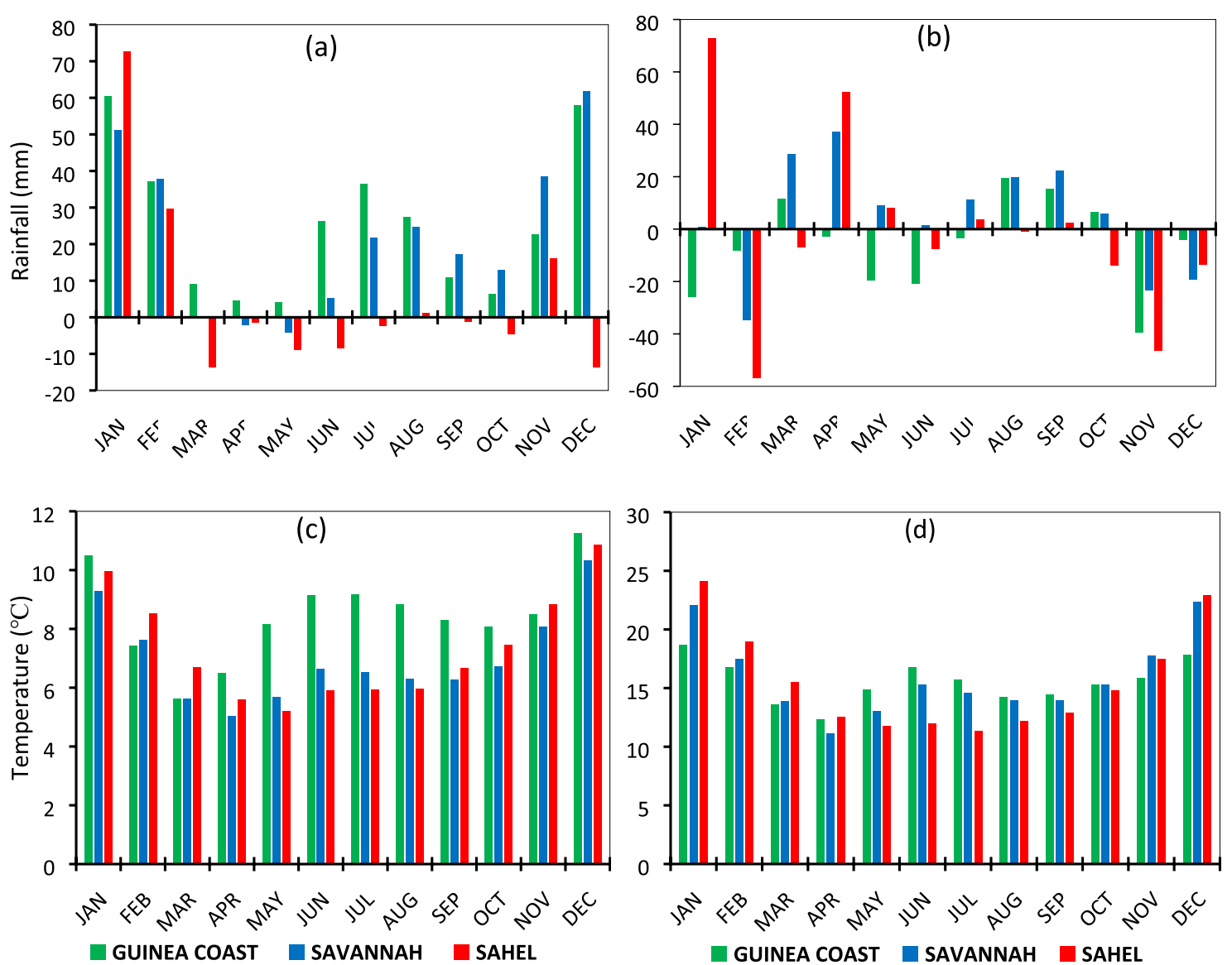

Fig. 6 Near-future projected percentage change in the seasonal cycle of rainfall $(\mathbf{a}, \mathbf{b})$ and temperature $(\mathbf{c}, \mathbf{d})$ relative to baseline period under RCP4.5 (left panel) and RCP8.5 (right panel)

in global climate (Baines 2006) to be responsible for the projected anomalies in rainfall and temperature. Besides, this positive and negative deviation may be due to increasing in the mean (change point) between 0.52 to $0.69^{\circ} \mathrm{C}$ and 1.17 and $1.30{ }^{\circ} \mathrm{C}$ under RCP4.5 and RCP8.5 respectively (Table 6) as the effects of global warming are not uniform across the globe (IPCC 2007).

\subsection{Far-Future Rainfall and Temperature Pattern}

\subsubsection{Change Detection and Trend Analysis}

Extending the change point detection test into the far-future (2060-2099), the result drawn from the analysis of the three tests are presented in Table 8 . For the temperature series, the test shows that under RCP4.5 and over the three homogeneous climatic zones (Guinea Coast, Savannah, and the Sahel), a significant shift in mean will occur by the year 2077. While a change point of about $0.19{ }^{\circ} \mathrm{C}$ may occur in the Guinea Coast, 0.63 and $1.24{ }^{\circ} \mathrm{C}$ in Savannah and Sahel respectively, rainfall series in all the climatic zones are homogeneous under RCP4.5. Homogeneous nature of rainfall noticed under RCP4.5 also exist in all the climatic zones under RCP8.5 as expected significant change point was observed for the temperature series in all the three climatic zones within the range of 1.46 and $1.67{ }^{\circ} \mathrm{C}$ by 2080 and 2081 under RCP8.5. The observed significant change point expected in the far-future suspected to be a result of the projected increase in global temperature that could reach $3{ }^{\circ} \mathrm{C}$ before the end of the twenty-first century (Nikulin et al. 2018). Furthermore, temperature trend analysis (Table 9) shows a significant increasing trend over Guinea Coast, Savannah, and the Sahel with a magnitude of change to be between $0.025-0.033^{\circ} \mathrm{C}$ and $0.057-0.063^{\circ} \mathrm{C}$ under RCP4.5 and RCP8.5 respectively. However, an insignificant decreasing trend was noticed in rainfall over the Guinea Coast and Savannah while the Sahel likely to experience a significant decreasing trend with $-2.644 \mathrm{~mm} /$ year as the magnitude of change (Sen's slope). An insignificant decreasing trend in rainfall expected over the Guinea Coast as rainfall in the Savannah and Sahel show insignificant increasing trend under RCP4.5 for the far-future. Moreover, this significant 
Fig. 7 Near-future total annual rainfall anomaly over the $(\mathbf{c}, \mathbf{d})$ and Sahel $(\mathbf{e}, \mathbf{f})$ under (right panel) relative to historical (1961-2000) mean. The red curves on each plot represent non-linear trend obtained by two years moving average Guinea Coast $(\mathbf{a}, \mathbf{b})$, Savannah RCP4.5 (left panel) and RCP8.5
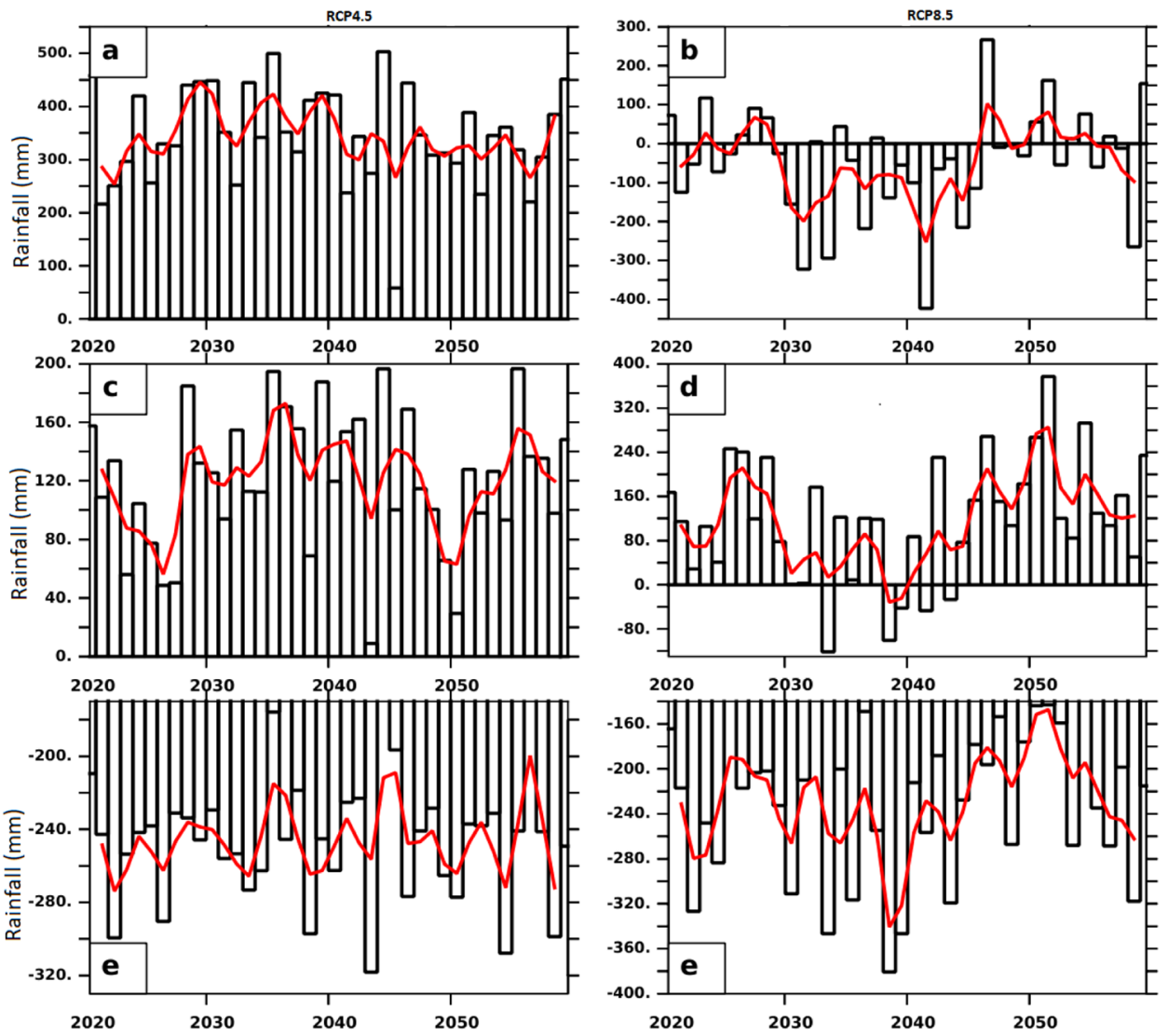

Fig. 8 Near-future annual mean temperature anomaly over the Guinea Coast (a, b), Savannah (c, d) and Sahel (e, f) under RCP4.5 (left pansel) and RCP8.5 (right panel) relative to historical (1961-2000) mean.

The red curves on each plot represent non-linear trend obtained by two years moving average
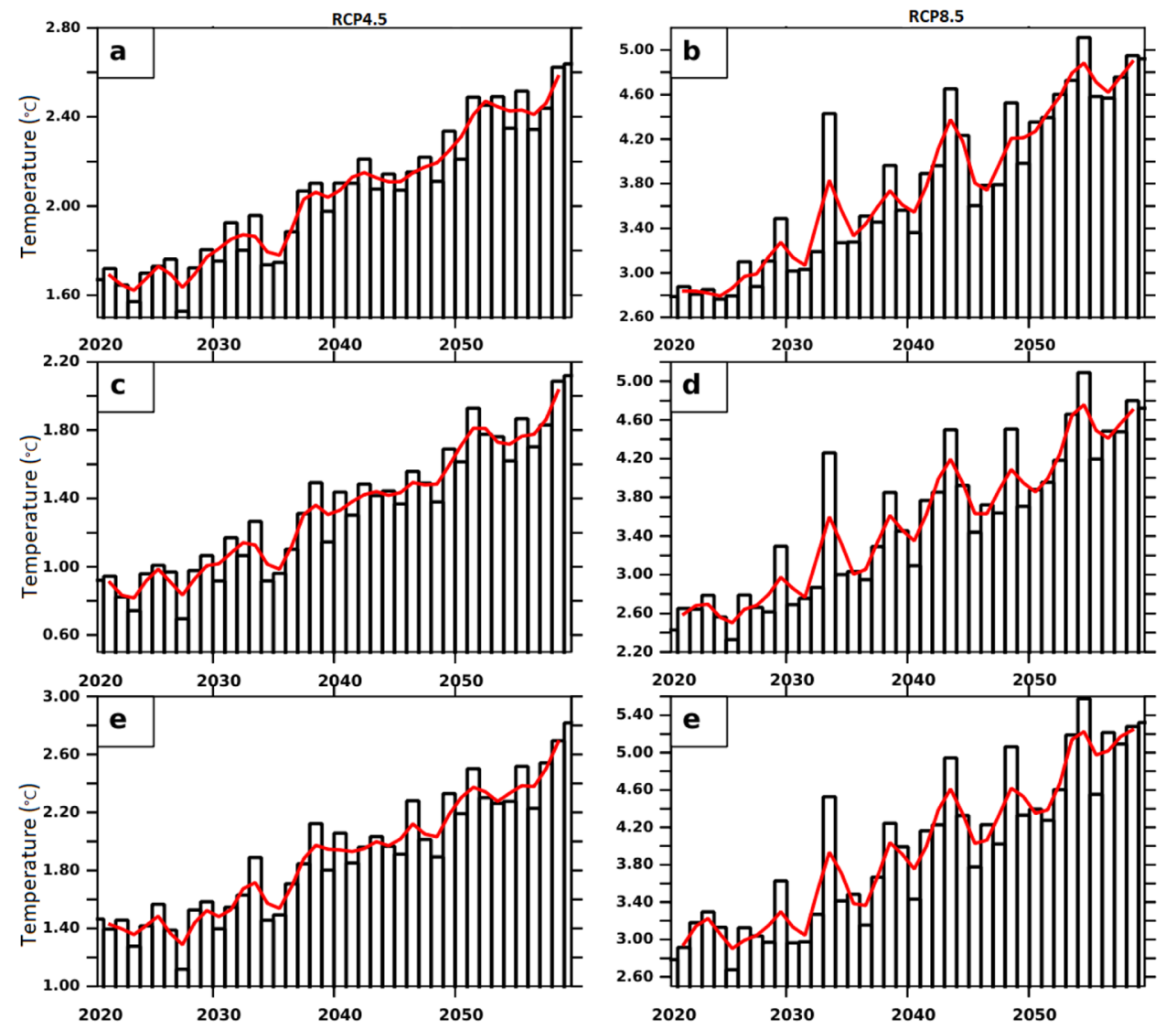
Table 8 Conclusion from the results of change point analysis of far-future ensemble-mean rainfall and temperature over the three climatic zones under RCP4.5 and RCP8.5 at 5\% significant level

\begin{tabular}{|c|c|c|c|c|c|c|c|c|c|c|c|}
\hline \multirow[t]{2}{*}{ Scenario } & \multirow[t]{2}{*}{ Climatic zone } & \multicolumn{5}{|l|}{ Rainfall } & \multicolumn{5}{|c|}{ Temperature } \\
\hline & & $\begin{array}{l}\text { Nature of } \\
\text { the series }\end{array}$ & Year of shift & $\mu 1$ & $\mu 2$ & diff & $\begin{array}{l}\text { Nature of } \\
\text { the series }\end{array}$ & Year of shift & $\mu 1$ & $\mu 2$ & diff \\
\hline \multirow[t]{3}{*}{$\mathrm{RCP} 4.5$} & Guinea Coast & HGN & - & 2182.07 & - & - & CPT & 2077 & 27.01 & 27.2 & 0.19 \\
\hline & Savannah & HGN & - & 1606.53 & - & - & CPT & 2077 & 27.01 & 27.64 & 0.63 \\
\hline & Sahel & $\mathrm{HGN}$ & - & 738.72 & - & - & CPT & 2077 & 28.71 & 29.95 & 1.24 \\
\hline \multirow[t]{3}{*}{ RCP8.5 } & Guinea Coast & $\mathrm{HGN}$ & - & 1789.89 & & - & CPT & 2081 & 28.58 & 30.04 & 1.46 \\
\hline & Savannah & $\mathrm{HGN}$ & - & 1568.38 & - & - & CPT & 2080 & 29.44 & 30.96 & 1.52 \\
\hline & Sahel & HGN & - & 735.32 & - & - & CPT & 2080 & 30.58 & 32.25 & 1.67 \\
\hline
\end{tabular}

$\mu 1$ and $\mu 2$ are the mean before and after the change point has occurred

Table 9 Result of trend analysis of far-future ensemble-mean rainfall and temperature under RCP4.5 and RCP8.5 at 5\% significant level

\begin{tabular}{lllllll}
\hline Scenario & $\begin{array}{l}\text { Climatic } \\
\text { zone }\end{array}$ & \multicolumn{2}{l}{ Rainfall } & & \multicolumn{2}{l}{ Temperature } \\
\cline { 3 - 4 } \cline { 6 - 7 } RCP4.5 & Guinea & 0.9164 & -0.045 & & $\mathbf{0 . 0 0 0 1}$ & 0.007 \\
& Coast & & & & \\
& Savannah & 0.2942 & 0.800 & & $\mathbf{0 . 0 0 1 9}$ & 0.008 \\
& Sahel & 0.8613 & 0.145 & & $\mathbf{0 . 0 0 0 9}$ & 0.010 \\
RCP8.5 & Guinea & 0.3393 & -1.657 & $\mathbf{0 . 0 0 1 1}$ & 0.072 \\
& Coast & & & & \\
& Savannah & 0.5840 & -1.000 & & $\mathbf{0 . 0 0 3 1}$ & 0.073 \\
& Sahel & $\mathbf{0 . 0 2 4 5}$ & -2.644 & & $\mathbf{0 . 0 0 2 8}$ & 0.079 \\
\hline
\end{tabular}

Bold figures represent a statistically significant trend

increasing trend in temperature has also been reported overa local area in west Africa by Collins (2011), Oguntunde et al. (2012) in Ibadan, Kabo-Bah et al. (2016) over the Volta river basin. Likewise, for the future, Bontogho (2015) also noticed an increase of $1.8{ }^{\circ} \mathrm{C}$ under RCP4.5 and $3.0^{\circ} \mathrm{C}$ under RCP8.5 in temperature in his study over Burkina Faso. A consistently increasing temperature trend of 5-10\% and 5-20\% under RCP4.5 and RCP8.5 respectively were reported by Oyerinde (2016) over the Niger river basin using eight ensembles RCMs. These results have shown that increase in the mean temperature over West Africa will be less than sub-local regions within West Africa by the end of twenty-first century while rainfall will be reduced in the Guinea Coast compared to other zones.

\subsubsection{Projected Relative Change in Seasonal Cycle Change and Inter-Annual Anomaly}

Projected change in the seasonal cycle for the far-future relative to historical long-term mean can be seen from Fig. 9. Over the Guinea Coast, it is observed that most of the months and season expected to have increase in monthly rainfall that could be more than $80 \%$ in January except March and April under RCP4.5 that could be drier than historical period (Fig. 9a). Drier condition up to $18 \%$ projected to occur in the spring (March-Mayay) within the Savannah. In the Sahel, both pre-monsoon and monsoon season are observed to have a decrease in rainfall projected under RCP4.5 (Fig. 9a). Under RCP8.5, extended monsoon months are expected to witness positive changes over the Guinea Coast and Savannah while other months and season expected also to have a decrease in rainfall amount (negative projected change) as high as $-80 \%$ for the three climatic zones. These results as it has been observed for the nearfuture agree with the projected extremes rainfall over Africa by Kitoh et al. (2013). The temperature under the two RCPs is expected to have a positive change in all the months. This means that most of the months and seasons in the far-future will be warmer relative to the historical period (Fig. 8a, b). In particular, winter (December, January, February) months are warmer than other months but this could only contribute to the projected positive change (increase) in rainfall for the winter months under RCP4.5 whereas it may result into a significant decrease in rainfall for the same winter months under RCP8.5 in all the three climatic zones of West Africa.

Figures 10 and 11 shows total annual rainfall and annual mean temperature anomaly relative to the historical longterm mean for the far-future projection. Rainfall anomaly for the Guinea Coast revealed that from 2060 to 2099, rainfall will be higher and wetter than historical mean under RCP4.5. While under RCP8.5, from 2060 to 2087, rainfall will be quasi-normal between $-240 \mathrm{~mm} /$ year and $240 \mathrm{~mm} /$ year but from 2088-2097 it will remain below the historical mean (Fig. 10a, b). Similarly, anomalies observed over the Guinea Coast was also noticed in the Savannah under RCP4.5 where rainfall will be above the historical mean in the far-future. For the same Savannah zone under RCP8.5, rainfall is projected to be above the historical mean for most of the years in the far-future except for the few years in which rainfall expected to be below historical mean. In 
Fig. 9 Far-future projected percentage change in the seasonal cycle of rainfall $(\mathbf{a}, \mathbf{b})$ and temperature $(\mathbf{c}, \mathbf{d})$ relative to the historical period under RCP4.5 (left panel) and RCP8.5 (right panel)
Fig. 10 Far-future total annual rainfall anomaly over the Guinea Coast $(\mathbf{a}, \mathbf{b})$, Savannah $(\mathbf{c}, \mathbf{d})$ and Sahel $(\mathbf{e}, \mathbf{f})$ under RCP4.5 (left panel) and RCP8.5 (right panel) relative to historical (1961-2000) mean. The red curves on each plot represent non-linear trend obtained by two years moving average
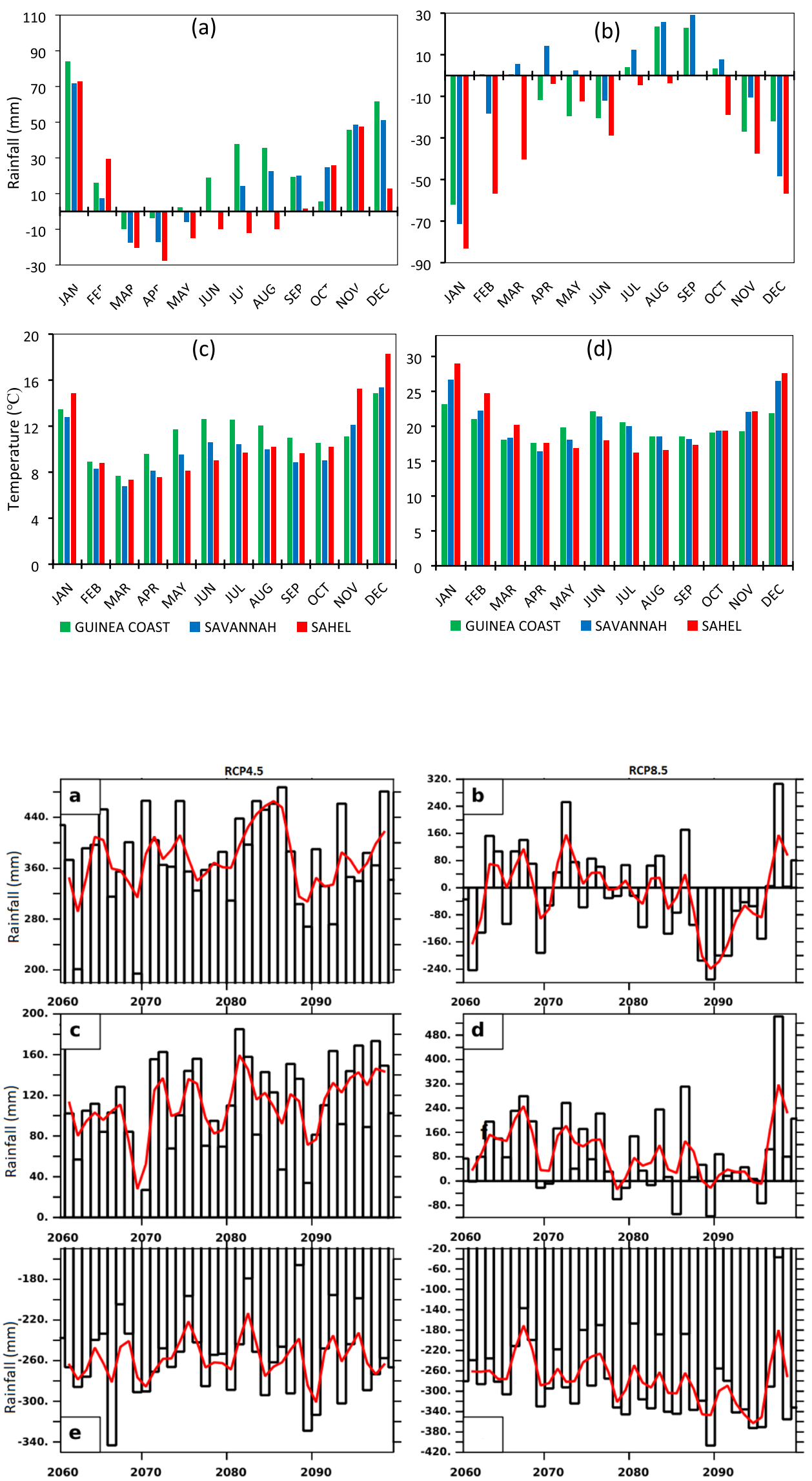
Fig. 11 Far-future annual mean temperature anomaly over the Guinea Coast (a, b), Savannah $(\mathbf{c}, \mathbf{d})$ and Sahel $(\mathbf{e}, \mathbf{f})$ under RCP4.5 (left panel) and RCP8.5 (right panel) relative to historical (1961-2000) mean. The red curves on each plot represent non-linear trend obtained by 2 years moving average
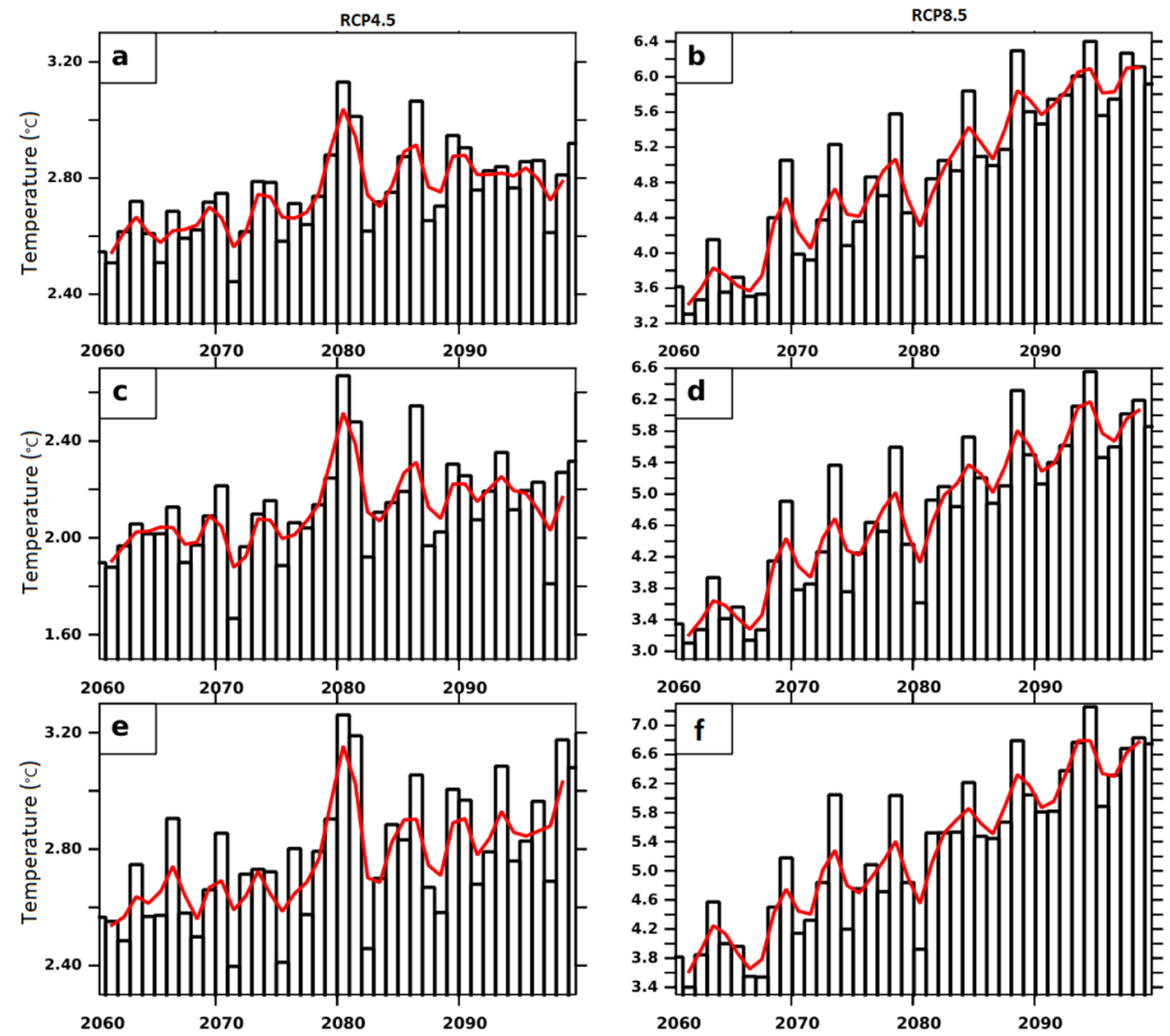

the Sahel, it is observed that rainfall will be significantly below the historical mean for all the years in the far-future (2060-2099) under the two emission scenarios. The temperature anomaly relative to historical long-term mean shown in Fig. 11 revealed also that over the three homogeneous climatic zones, the temperature is projected to be warmer than the historical period under RCP4.5 and RCP8.5 with the later higher than the former. Also, the rate of increase in temperature relative to historical mean was noticed to be higher under RCP8.5 when compared to lower emission scenarios (RCP4.5). Since the warmer atmosphere can hold larger moisture (Lenderink and Meijgaard 2010), the projected increase in rainfall relative to the historical mean over the Guinea Coast and Savannah may be associated with the expected increase $n$ temperature.

\section{Summary and Conclusion}

Ensemble mean of six RCMs driven by five GCMs obtained from the archive of CORDEX was used in this study over the historical (1961-2000) and projected (2020-2099) periods over three climatic regions of West Africa. The projected period was further divided into near-future (2020-2059) and far-future (2060-2099) as most of the RCMs agreed that warming level of $2{ }^{\circ} \mathrm{C}$ would have been achieved by the year 2060. Change-point detection and trend analysis were performed using a non-parametric statistical test. Standard normal homogeneity test, Buishand's range test, and Pettitt's test have been used to detect change point while the Mann-Kendall test was also used to examine trends in rainfall and temperature long-term series at the annual scale. The capabilities of the ensemble mean of the RCMs to detect change point and reproduce seasonal cycle was firstly assessed by comparing its results to that of CRU for the historical period. Also, the projected change in seasonal cycle and the anomaly of temperature and rainfall relative to historical mean was further investigated to examine how near and far-future rainfall and temperature will deviate from the historical period. The results are summarized as follows:

- The ensemble mean used reproduced the observed seasonal variation and pattern of rainfall and temperature as seen from the CRU over the three agro-climatic zones. Though, a zonal variation in rainfall amount and temperature values were well captured by the ensemble mean but with little difference in the magnitude of the various peak of rainfall and temperature.

- At a 5\% significant level, both the ensemble mean and CRU observation agree that a significant change point 
in temperature and rainfall occurred in the 1970s and 1980s decades in all three climatic zones. These are well-known decades with prolonging droughts over west Africa as a statistical significant increase in temperature was observed in the two datasets.

- In the near-future, rainfall expected to be homogeneous over the three climatic zones under RCP4.5 while only Savannah will be heterogeneous under RCP8.5 to have a shift of $105.18 \mathrm{~mm}$ of rainfall by 2044. A significant change point in temperature over the three climatic zones is also expected by the year 2040 under RCP8.5 that may lead to an increase of $1.17-1.30{ }^{\circ} \mathrm{C}$ in the temperature mean. Likewise, under RCP4.5, change point in rainfall may occur by 2036 and 2037 over the Guinea Coast and Sahel respectively but remains doubtful over the Savannah. Trend analysis projects an insignificant increase in rainfall and a significant increase in temperature over the three climatic zones under both RCPs.

- Projected change in seasonal cycle relative to the historical period for the near-future revealed that winter months will receive more rainfall under RCP4.5 while the temperature will be warmer in all the months under both pathways with more warming under RCP8.5. Annual anomaly relative to historical long-term mean projects Guinea Coast and Savannah to have increased rainfall amount under RCP4.5, rainfall in the Sahel will be reduced under the two emission scenarios as temperature expected to be warmer than the historical period under RCP4.5 and RCP8.5.

- In the far-future, rainfall expected will remain homogeneous under the two emission scenarios, change point expected to occur by 2077 under RCP4.5 while it will be between 2080 and 2081 under RCP 8.5 in all the zones. A positive shift in the temperature means that could reach $1.67{ }^{\circ} \mathrm{C}$ projected across the three climatic zones under the two emission scenarios as increasing temperature trend will be statistically significant.

- In the same far-future, winter months expected to witness an increase in rainfall amount in all the climatic zones under RCP4.5, and only Guinea Coast and Savannah expected to have increase rainfall amount in monsoon months under RCP8.5. Projected change in temperature seasonal cycle relative to the historical period will be warmer under the two RCPs in all climatic zones. Also, rainfall anomaly revealed that the Sahel will continue to have a lesser amount of rainfall as the annual mean temperature will continue to rise under the two scenarios till the end of the twenty-first century in all the three climatic zones of West Africa.

- The results of this study shows the importance of using multiple statistical techniques by climate scientist to examine and analyze climate data at any level to reduce uncertainty in the information giving to policymakers and end users.

Hence these results corroborate earlier findings and stretch the need for all countries in West Africa to develop and promote coordinated regional effort by choosing the right sustainable adaptation plan to mitigate against the potential effects of climate change caused by increasing human activities. Lastly, the work can be improved by examine the impacts of climate change on other climatic variables.

Acknowledgements The authors acknowledged the Climate Research Unit (CRU), University of East Anglia, for the observational dataset used in this study and also appreciate Coordinated Regional Climate Downscaling Experiment (CORDEX) for making the simulation dataset used in this study available to the general public.

\section{Compliance with Ethical Standards}

Conflict of interest The two authors declare that there is no conflict of interest in any form or so associated with the publication of this work.

Open Access This article is licensed under a Creative Commons Attribution 4.0 International License, which permits use, sharing, adaptation, distribution and reproduction in any medium or format, as long as you give appropriate credit to the original author(s) and the source, provide a link to the Creative Commons licence, and indicate if changes were made. The images or other third party material in this article are included in the article's Creative Commons licence, unless indicated otherwise in a credit line to the material. If material is not included in the article's Creative Commons licence and your intended use is not permitted by statutory regulation or exceeds the permitted use, you will need to obtain permission directly from the copyright holder. To view a copy of this licence, visit http://creativecommons.org/licenses/by/4.0/.

\section{References}

Abiodun BJ, Salami AT, Matthew OJ, Odedokun S (2013) Potential impacts of aforestation on climate change and extreme events in Nigeria. Clim Dyn 41(2):277-293. https://doi.org/10.1007/ s00382-012-1523-9

Adefisan EA (2018) Climate change impact on rainfall and temperature distributions over West Africa from three IPCC scenarios. J Earth Sci Clim Change 9:476. https://doi.org/10.4172/21577617.1000476

Adeniyi MO, Oladiran EO (2000) Air sea interaction: ENSO phenomenon as it affects periodicity of flooding in Nigeria. J Sci Res 6(1):30-35

Afiesimama EA, Pal JS, Abiodun BJ, Gutowski WJ Jr, Adedoyin A (2006) Simulation of West African monsoon using the RegCM3. Part I: model validation and interannual variability. Theor Appl Climat 86(1-4):23-37

Ahmed SA, Diffenbaugh NS, Hertel TW (2009) Climate volatility deepens poverty. Environ Res Lett. https://doi.org/10.1088/17489326/4/3/034004

Ajayi VO, Ilori OW (2020) Projected drought events over west africa using RCA4 regional climate model. Earth Syst Environ. https ://doi.org/10.1007/s41748-020-00153-x 
Akinsanola AA, Ogunjobi KO (2014) Analysis of rainfall and temperature variability over Nigeria. Glob J Hum Soc Sci 14(3):1-8

Akinsanola AA, Ogunjobi KO (2015) Recent homogeneity analysis and long-term spatiotemporal rainfall trends in Nigeria. Theor Appl Climatol. https://doi.org/10.1007/s00704-015-1701-x

Akinsanola AA, Zhou W (2018) Projections of West African summer monsoon rainfall extremes from two CORDEX models. Clim Dyn. https://doi.org/10.1007/s00382-018-4238-8

Akinsanola AA, Ogunjobi KO, Gbode IE, Ajayi VO (2015) Assessing the capabilities of three regional climate models over CORDEX Africa in simulating West African summer monsoon precipitation. Adv Meteorol 2015:1-13. https://doi. org/10.1155/2015/935431

Alexandersson HA (1986) A homogeneity test applied to precipitation data. Int J Climatol 6:661-675

Alexandersson H, Moberg A (1997) Homogenization of Swedish temperature data. Part I: a homogeneity test for linear trends. Int J Climatol 17:25-34

Alexander LV, Zhang X, Peterson TC, Caesar J, Gleason B, Klein Tank AMG, Haylock M, Collins D, Trewin B, Rahimzadeh F, Tagipour A, RupaKumar K, Revadekar J, Griffiths G, Vincent L, Stephenson DB, Burn J, Aguilar E, Brunet M, Taylor M, New M, Zhai P, Rusticucci M, Vazquez-Aguirre JL (2006) Global observed changes in daily climate extremes of temperature and precipitation. J Geophys Res 111(D5)

Ati OF, Stitger CJ, Oladipo EO (2002) A comparison of methods to determine the onset of the growing season in northern Nigeria. Int J Climatol 22:731-742

Ayansina A, Ogunbo S (2009) GIS approach in assessing seasonal rainfall variability in Guinea Savanna Part of Nigeria. 7th FIG regional conference, Vietnam, 19-22 October 2009, p 16

Badou DF, Kapangaziwiri E, Diekkrüger B, Hounkpè J, Afouda AA (2017) Evaluation of recent hydro-climatic changes in four tributaries of the Niger River Basin (West Africa). Hydrol Sci J 62:715-728. https://doi.org/10.1080/02626667.2016.1250898

Baines PG (2006) The late 1960s global climate shift and its influence on the southern hemisphere. In: Proceedings of 8th ICSHMO. Brazil, INPE, pp 1477-1482

Bhavnani R, Vordzorgbe S, Owor M, Bousquet F (2008) Disaster risk reduction in the Sub-Saharan Africa Region. Commission of the African Union, Washington, DC

Biasutti M (2013) Forced Sahel rainfall trends in the CMIP5 archive. J Geophys Res Atmos 118:1613-1623. https://doi.org/10.1002/ jgrd.50206

Bontogho TNPE (2015) Modeling a Sahelian water resource allocation under climate change and human pressure: case of Loumbila dam in Burkina Faso. Ph.D. Dissertation, Université d'AbomeyCalavi, Cotonou, Benin

Buishand TA (1982) Some methods for testing the homogeneity of rainfall records. J Hydrol 58(1-2):11-27

Charney J, QuirkWJ CSH, Kornfield J (1977) A comparative study of the effects of albedo change on drought in semi-arid regions. J Atmos Sci 34:1366-1385. https://doi.org/10.1175/1520-0469

Climate Change Science Program, Karl Thomas R, Meehl Gerald A, Miller Christopher D, Hassol Susan J, Waple Anne M, Murray WL (eds) (2008) Weather and climate extremes in a changing climate. Regions of focus: North America, Hawaii, Caribbean, and U.S. Pacific Islands. Department of Commerce, NOAA's National Climatic Data Center, Washington, DC

Collins JM (2011) Temperature variability over Africa. J Clim 24:3649-3666. https://doi.org/10.1175/2011JCLI3753.1

Cook KH (1999) Generation of the African easterly jet and its role in determiningWest African precipitation. J Clim 12(5):1165-1184

Diallo I, Sylla MB, Giorgi F, Camara M, Gaye AT (2012) Multimodel GCM-RCM ensemble-based projections of temperature and precipitation over West Africa for the early 21 st century. Int J Geophys 2012:1-19

Diallo I, Sylla MB, Camara M, Gaye AT (2013) Interannual variability of rainfall over the Sahel based on multiple regional climate models simulations. Theor Appl Clim 113 (1-2):351-362

Dhorde AG, Zarenistanak M (2013) Three-way approach to test data homogeneity: an analysis of temperature and precipitation series over southwestern Islamic Republic of Iran. J Ind Geophys Union 17(3):233-242

Dieterich C, Schimanke S, Wang S, Väli G, Liu Y et al (2013) Evaluation of the SMHI coupled atmosphere-ice-ocean model RCA4NEMO. pp 1-80

Dong BW, Sutton R (2015) Dominant role of greenhouse gas forcing in the recovery of Sahel rainfall. Nat Clim Change 5:757-760. https://doi.org/10.1038/nclimate2664

Ekpoh IJ, Nsa E (2011) Extreme climatic variability in Northwestern Nigeria: an analysis of rainfall trends and patterns. J Geogr Geol 3(1):51-62

Emmanuel LA, Hounguè NR, Biaou CA, Badou DF (2019) Statistical analysis of recent and future rainfall and temperature variability in the mono river watershed (Benin, Togo). Climate 7:8. https:// doi.org/10.3390/cli7010008

Farmer G, Wigley TML (1985) Climatic trends for tropical Africa. Research Report for Overseas Development Administration. SMHI Report Oceanography No. 47, SMHI, Norrköping. Climatic Research Unit, University of East Anglia, Norwich, England, p 136

Fasona M, Tadros M, Abiodun B, Omojola A (2011) Local climate forcing and eco-climatic complexes in the wooded savannah of western Nigeria. Nat Res 2:155-166. https://doi.org/10.4236/ nr.2011.23021

Fink AH (2003) Spatiotemporal variability of the relation between African Easterly Waves and West African squall lines in 1998 and 1999. J Geophys Res 108 (D11)

Food and Agricultural Organization (2001) Global forest resources assessment 2000. Main Report Forestry Paper 140, Rome

Gallagher C, Lund R, Robbins M (2012) Change point detection in climate time series with long-term trends. J Clim 26:4994-5006. https://doi.org/10.1175/JCLI-D-12-00704.1

Gao P, Mu XM, Wang F, Li R (2011) Changes in streamflow and sediment discharge and the response to human activities in the middle reaches of the Yellow River. Hydrol Earth Syst Sci 15:1-10

Gbobaniyi E, Sarr A, Sylla MB, Diallo I, Lennard C, Dosio A et al (2014) Climatology, annual cycle and interannual variability of precipitation and temperature in CORDEX simulations over West Africa. Int J Climatol 34:2241-2257

Gbode IE, Adeyeri OE, Menang KP, Intsiful JDK, Ajayi VO, Omotosho JA, Akinsanola AA (2019) Observed changes in climate extremes in Nigeria. Meteorol Appl. https://doi.org/10.1002/ met.1791

Giorgi F, Jones C, Asrar GR (2009) Addressing climate information needs at the regional level: the CORDEX framework. World Meteorol Org WMO Bull 58(3):175

Gonzalez-Rouco JF, Jimenez JL, Quesada V, Valero F (2001) Quality control and homogeneity of precipitation data in the southwest of Europe. Int J Climatol 14:964-978

Hagos SM, Cook KH (2007) Dynamics of the West African monsoon jump. J Clim 20(21):5264-5284. https://doi.org/10.1175/2007J CLI1533.1

Harris I, Jone PD, Osborn TJ, Lister DH (2014) Updated high-resolution grids of monthly climatic observations-the CRUTS3.10 dataset. Int J Climatol 34:623-642. https://doi.org/10.1002/ joc. 3711

Hounkpè J, Diekkrüger B, Badou DF, Afouda AA (2016) Change in heavy rainfall characteristics over the Ouémé River Basin, 
Benin Republic. West Afr Clim 4:15. https://doi.org/10.3390/ cli4010015

Ibrahim B, Karambiri H, Polcher J, Yacouba H, Ribstein P (2014) Changes in rainfall regime over Burkina Faso under the climate change conditions simulated by 5 regional climate models. Clim Dyn 42:1363-1381. https://doi.org/10.1007/s00382-013-1837-2

IPCC (2013) the physical science basis. In: Stocker TF, Qin D, Plattner GK, Tignor M, Allen SK, Boschung J, Nauels A, Xia Y, Bex V, Midgley PM (eds) Contribution of working group I to the fifth assessment report of the intergovernmental panel on climate change. Cambridge University Press, Cambridge, p 1535. https ://doi.org/10.1017/CBO9781107415324

IPCC (2014) Impacts, adaptation, and vulnerability. Part A: global and sectoral aspects. Contribution of working group II to the fifth assessment report of the intergovernmental panel on climate change. Cambridge University Press, Cambridge

IPCC (2007a) The physical science basis. In: Saloman S, Qin D, Manning M, Chan Z, Marquis M, Averyt KS, Tignor M, Miller HL (eds) Contribution of working group I, II and III ti the Third assessment report of IPCC. Cambridge Uni. Press, New York, p 966

IPCC (2007b) Climate change 2007: synthesis report. In: Core Writing Team, Pachauri RK, Reisinger A(eds) Contribution of working groups i, ii and iii to the fourth assessment report of the intergovernmental panel on climate change. IPCC, Geneva, Switzerland, p 104

Jaiswal RK, Lohani AK (2015) Tiwari HL (2019) Statistical analysis for change detection and trend assessment in climatological parameters. Environ Process 2:729-749. https://doi.org/10.1007/ s40710-015-0105-3

Kabo-Bah A, Diji C, Nokoe K, Mulugetta Y, Obeng-Ofori D, Akpoti K (2016) Multiyear rainfall and temperature trends in the volta river basin and their potential impact on hydropower generation in Ghana. Climate 4:49

Kang HF, Yusof F (2012) Homogenity test on daily rainfall series in Peninsular Malasiya. Int J Contemp Math Sci 7(1):9-22

Karmeshu N (2012) Trend detection in annual temperature and precipitation using the Mann Kendall Test-a case study to assess climate change on select states in the Northeastern United States. Master of Environment Studies Capstone project, University of Pennsylvania USA. https://repository.upenn.edu/mes_capst ones $/ 47$

Kendall MG (1975) Rank correlation methods. Charles Griin book series. E. Arnold, London

Kim J, Waliser DE, Mattmann CA (2014) Evaluation of the CORDEX-Africa multi-RCM hindcast: systematic model errors. Clim Dynam 42(5-6):1189-1202

Kitoh A et al (2013) Monsoons in a changing world: a regional perspective in a global context. J Geophys Res Atmos. https://doi. org/10.1002/jgrd.502580

Lambert SJ, Boer GJ (2001) CMIP1 evaluation and intercomparison of coupled climate models. Clim Dyn 17:83-106. https://doi. org/10.1007/PL00013736

Lawin AE, Manirakiza C, Batablinlè L (2018) Trends and changes detection in rainfall, temperature and wind speed in Burundi. J Water Clim Change. https://doi.org/10.2166/wcc.2018.155

Le Barbé L, Lebel L, Tapsoba D (2002) Rainfall variability in West Africa during the years 1950-90. J Clim 15:187-202

Lebel T (2003) Seasonal cycle and interannual variability of the Sahelian rainfall at hydrological scales. J Geophys Res 108(D8)

Lebel T, Ali A (2009) Recent trends in the Central and Western Sahel rainfall regime (1990-2007). J Hydrol 375(1-2):52-64

Lenderink G, van Meijgaard E (2010) Linking increases in hourly precipitation extremes to atmospheric temperature and moisture changes. Environ Res Lett 5:025208. https://doi. org/10.1088/1748-9326/5/2/025208
Lin R, Zhou T, Qian Y (2014) Evaluation of global monsoon precipitation changes based on five reanalysis datasets. J Clim 27(3):1271-1289. https://doi.org/10.1175/JCLI-D-13-00215.1

Mann HB (1945) Nonparametric tests against trend. Econometrica 13:245-259

Mauget SA (2003) Intra to multi-decadal climate variability over the continental United States. Int J Climatol 16:2215-2231. https:// doi.org/10.1175/2751.1

Meissner K, Weaver A, Matthews H, Cox P (2003) The role of land surface dynamics in glacial inception: a study with the UVic earth system model. Clim Dyn 21:515-537

Mohino E, Janicot S, Bader J (2011) Sahel rainfall and decadal to multi-decadal sea surface temperature variability. Clim Dyn 37:419-440. https://doi.org/10.1007/s00382-010-0867-2

Moss R, Edmonds J, Hibbard K, Manning M, Rose S, van Vuuren D et al (2010) The next generation of scenarios for climate change research and assessment. Nature 463:747-756

Mu X, Zhang L, McVicar TR, Chille B, Gau P (2007) Analysis of the impact of conservation measures on stream flow regime in catchments of the Loess Plateau, China. Hydrol Process 21:2124-2134

N'Tcha M'Po Y, Lawin E, Yao B, Oyerinde G, Attogouinon A, Afouda A (2017) Decreasing past and mid-century rainfall indices over the Ouémé River Basin, Benin (West Africa). Climate 5:74. https ://doi.org/10.3390/cli5030074

Nelson GC, Rosegrant MW, Palazzo A, Gray I, Ingersoll C, Robertson R, Tokgoz S (2010) Food security, farming, and climate change to 2050: scenarios, results, policy options. International Food Policy Research Institute, Washington DC

Nicholson SE (2013) The West African Sahel: a review of recent studies on the rainfall regime and its interannual variability. ISRN Meteorol 2013:32. https://doi.org/10.1155/2013/453521

Nikulin G, Jones C, Giorgi F, Asrar G, Büchner M, Cerezo-Mota R, Christensen OB, Déqué M, Fernandez J, Hänsler A, van Meijgaard E (2012) Precipitation climatology in an ensemble of CORDEX-Africa regional climate simulations. J Clim 25(18):6057-6078

Nikulin G, Lennard C, Dosio A, Kjellstrom E, Chen Y, Hansler A, Kupiainen M, Laprise R, Mariotti L, Maule CF, van Meijgaard E, Panitz HJ, Scinocca JF, Somot S (2018) The effects of 1.5 and 2 degrees of global warming on Africa in the CORDEX ensemble. Environ Res Lett 13(6):065003

Oguntunde PG, Abiodun BJ, Lischeid G (2011) Rainfall trends in Nigeria, 1901-2000. J Hydrol 411:207-218. https://doi.org/10.1016/j. jhydrol.2011.09.037

Oguntunde PG, Abiodun BJ, Olukunle OJ, Olufayo AA (2012) Trends and variability in pan evaporation and other climatic variables at Ibadan, Nigeria, 1973-2008. Meteorol Appl 19:464-472. https ://doi.org/10.1002/met.281

Omotosho JB, Abiodun BJ (2007) A numerical study of moisture buildup and rainfall over West Africa. Meteorol Appl 14(3):209-225. https://doi.org/10.1002/met11

Oyerindé GT (2016) Climate change in the Niger River Basin on hydrological properties and functions of Kainji Lake,West Africa. $\mathrm{Ph}$.D. Dissertation, Université d'Abomey-Calavi, Cotonou, Benin

Paeth H, Hall NMJ, Gaertner MA (2011) Progress in regional downscaling of west African precipitation. Atmos Sci Lett 12(1):75-82

Panitz HJ, Dosio A, Büchner M, Lïthi D, Keuler K (2014) COSMOCLM (CCLM) climate simulations over CORDEX-Africa domain: analysis of the ERA-Interim driven simulations at 0.44 and 0.22 resolution. Clim Dyn 42:3015. https://doi.org/10.1007/ s00382-013-1834-5

Pant GB (2003) Long-term climate variability and change over monsoon Asia. J Indian Geophys Union 7(3):125-134

Pettitt AN (1979) A non-parametric approach to the change point problem. J Appl Stat 28(2):126-135 
Ravindran PN, Nirmal Babu K, Sasikumar B, Krishnamurthy KS (2000) Botany and crop improvement of black pepper. In: Ravindran PN (ed) Black pepper. Harwood Academic Publishers, Reading, pp 23-142

Salarijazi M, Ali Mohammad AA, Adib A, Daneshkhan A (2012) Trend and change-point detection for the annual stream-flow series of the Karun River at the Ahvaz hydrometric station. Afr J Agric Reserv 7(32):4540-4552

Sanogo S, Fink AH, Omotosho JA, Ba A, Redl R, Ermert V (2015) Spatio-temporal characteristics of the recent rainfall recovery in West Africa. Int J Climatol 35:4589-4605. https://doi. org/10.1002/joc.4309

Savitskaya D (2010) Statistical picture of climate changes in Central Asia: Temperature, precipitation, and river flow. In: Swayne DA, Yang W, Voinov AA, Rizzoli A, Filatova T (eds) Proceedings of the International Environmental Modelling and Software Society (iEMSs) International Congress on Environmental Modelling and Software Modelling for Environment's Sake, Ottawa, ON, Canada, 5-8 July 2010. iEMS, Manno, Switzerland

Schaefer D, Domroes M (2009) Recent climate change in Japan-spational and temporal characteristics of trends of temperature. Clim Past 5:13-19

Sivakumar T, Thennarasu A, Rajkumar JSI (2012) Effect of season on the incidence of infectious diseases of bovine in Tamilnadu. Elixir Meteorol 47:8874-8875

Snyder PK, Delire C, Foley JA (2004) Evaluating the influence of different vegetation biomes on the global climate. Clim Dyn 23:279-302

Stepanek P, Zahradnek P, Skalak P (2009) Data quality control and homogenization of air temperature and precipitation series in the area of Czech Republic in the period of 1961-2007. Int J Glob Energy. https://doi.org/10.1504/IJGGI.2009.030657

Sultan B, Janicot S (2003) The West African monsoon dynamics. Part II: the "Preonset" and "Onset" of the summer monsoon. J Clim 16 (21):3407-3427

Sylla MB, Diallo I, Pal JS (2013) West African monsoon in state-of the-art regional climate models. In: Tarhule A (ed) Climate variability—regional and thematic patterns. InTech, London
Sylla MB, Nikiema PM, Gibba P, Kebe I, Klutse NAB (2016a) Climate change over West Africa: recent trends and future projections. Springer, New York. https://doi.org/10.1007/978-3-319-31499 $-03$

Tabari H, Marofi S, Aeini A, Talaee PH, Mohammadi K (2011) Trend analysis of reference evapotranspiration in the western half of Iran. Agric For Meteorol 151:128-136

van Vuuren DP, Edmonds J, Kainuma M, Riahi K, Thomson A, Hibbard K, Hurtt GC, Kram T, Krey V, Lamarque JF, Masui T, Meinshausen M, Nakicenovic N, Smith SJ, Rose SK (2011) The representative concentration pathways: an overview. Clim Change 109(1-2):5-31. https://doi.org/10.1007/s10584-011-0148-z

Vezzoli R, Pecora S, Zenoni E, Tonneli F (2012) Inhomogeneity, change points, trends in observations: an application to Po river discharge extremes. Centre Euro-Mediterraneo Sui Combiamenti Climatici (CMCC) Research Paper RP0138, pp 1-15

Vincent LA, Peterson TC, Barros VR, Marino MB, Rusticucci M, Carrasco G, Ramirez E, Alves LM, Ambrizzi T, Berlato MA (2015) Observed trends in indices of daily temperature extremes in South America 1960-2000. J Clim 18:011-5024. https://doi. org/10.1175/JCLI3589.1

Wang W, Van Gelder PHAJM, Vrijling JK (2005) Trend and stationarity analysis for streamlow processes of rivers in Western Europe in the 20th century. In: Proceedings of the IWA international conference on water economics, statistics, and inance, Rethymno, Greece, 8-10, p 810

Winingaard JB, Kleink Tank AMG, Konnen GP (2003) Homogeneity of 20th century european daily temperature and precipitation series. Int J Climatol 23:679-692

World Population Prospect (2019) Population division of uinted nation department of economic and social affairs. https://population.un. org

Yu PS, Yang TC, Kuo CC (2006) Evaluating long-term trends in annual and seasonal precipitation in Taiwan. Water Resour Manag 20:1007-1023. https://doi.org/10.1007/s11269-006-9020-8

Yue S, Hashino M (2003) Long term trends of annual and monthly precipitation in Japan. J Am Water Resour 39(3):587-596 